\title{
COUNTER-CYCLICAL BANKRUPTCY LAW: AN EFFICIENCY ARGUMENT FOR EMPLOYMENT-PRESERVING BANKRUPTCY RULES
}

\author{
Zachary Liscow*
}

\begin{abstract}
Bankruptcy judges consider both value to creditors and harm to employees in deciding whether to liquidate or reorganize firms. This Article proposes to systematize what is currently an ad hoc trade-off by making bankruptcy law explicitly counter-cyclical-that is, placing more weight on preserving employment during times of high unemployment. Although the suggestion that bankruptcy law should consider employment effects muns counter to decades of economic analysis of bankruptcy law, this Article bases its analysis on the traditional law and economics efficiency norm. During times of high unemployment, significant social benefits flow from maintaining employment, as evidenced by the hundreds of billions of dollars that the government has recently spent to maintain employment. The simple argument of this Article is that when bankruptcy law can preserve employment more cheaply than government spending can, it should do so.
\end{abstract}

INTRODUCTION

I. EFFICIENT BANKRUPTCY LAW AND EFFICIENT LEGAL RULES..................1466

A. The Broader Debate About Efficient Legal Rules ....................1466

B. "Community Concerns": "Proceduralists" Versus "Traditionalists" in Bankruptcy Law .................................................................1467

II. MODEL OF BANKRUPTCY AND EMPLOYMENT .....................................1468

A. Background Macroeconomic Literature.................................1468

B. Basic Setup ....................................................................1471

C. Two Methods for Estimating the Value of Maintaining

Employment

D. Accounting for Context Dependence

III. IMPLEMENTING COUNTER-CYCLICAL BANKRUPTCY LAW .....................1483

A. Implementation Using $§ 1112$ (b) Under Current Statute ........1484

B. Other Means of Implementing Counter-Cyclical Bankruptcy Law Under Current Statute ...........................................................1486

C. Statutory Changes to Implement Counter-Cyclical Bankruptcy Law

IV. EXAMPLE APPLICATION 1489

* Associate Professor, Yale Law School. Thanks to Al Klevorick and Alan Schwartz for their long lists of insights. I also wish to thank Anne Alstott, Ken Ayotte, Ian Ayres, Douglas Baird, Nick Bloom, Ed Fox, Judge Andrew Hurwitz, David Liscow, Yair Listokin, Michael Marvin, Jonathan Masur, Andrew Metrick, John Morley, Roberta Romano, Sarath Sanga, Damian Schaible, David Schleicher, Judge Stephen Williams, William Woolston, and the editors at the Columbia Law Review for helpful comments and conversations. 
V. RESPONDING TO POTENTIAL CRITIQUES................................................1495

A. The Institutional Competency of the Bankruptcy System .......1495

B. Asymmetry with Law Outside of Bankruptcy ...........................1497

C. Alternative Policies Would Be Superior ...................................1498

D. Re-Entry into Bankruptcy ....................................................1499

E. Few Bankruptcies Take Place During Times of High Unemployment

CONCLUSION

\section{INTRODUCTION}

Suppose that a bankruptcy judge has two options in a bankruptcy proceeding of a factory. First, the judge could reorganize the factory, resulting in a $\$ 1,000,000$ payment to creditors and keeping the factory largely intact. Second, the judge could liquidate the factory, resulting in a $\$ 1,500,000$ payment to creditors and the loss of 1,000 jobs as the factory is shuttered. What should the bankruptcy judge choose? Conventional law and economics analysis dictates shuttering the plant to maximize the return to creditors and thereby maximize efficiency. Contrary to the prevailing view in law and economics, this Article argues that during times of high unemployment the judge should instead choose reorganization in order to preserve jobs, despite the lower payment to creditors. Doing so can reduce the suffering caused by unemployment while also reducing costs to taxpayers.

The argument rests solely on economic efficiency. During and around recessions, ${ }^{1}$ an inefficiently large number of people are unemployed, and both worker surplus (the gain that workers receive over the cost of providing labor) and producer surplus (profits) are lost. Keynesian stimulus programs seek to rectify this inefficiency, increasing employment in two ways. First, stimulus increases employment directly through increased government hiring and spending. Second, Keynesian stimulus does so indirectly through the "Keynesian multiplier." The Keynesian multiplier refers to the process by which an increase in government spending or reduction in taxes increases consumer spending among beneficiaries of the spending or tax cuts, in turn increasing employment among those who benefit from that increased consumer spending; these newly employed people spend more money because

1. A "recession," as used in this Article, is a time when the economy is operating significantly below its potential output, with consequent underutilization of capital and elevated unemployment. It does not mean just a contraction in economic output, as the term is sometimes technically taken to mean. See US Business Cycle Expansions and Contractions, Nat'l Bureau of Econ. Research, http://www.nber.org/cycles/ US_Business_Cycle_Expansions_and_Contractions_20120423.pdf [http://perma.cc/65DJYVYZ] (last visited Sept. 26, 2016) ("The NBER does not define a recession in terms of two consecutive quarters of decline in real GDP. Rather, a recession is a significant decline in economic activity spread across the economy...."). 
their own incomes have gone up, thereby causing the cycle to repeat itself. ${ }^{2}$ The government spends to mitigate the pain and reduce the efficiency losses of high unemployment in two ways. First, during times of high unemployment, governments typically spend money to increase employment. ${ }^{3}$ Indeed, the government spent over $\$ 800$ billion with this goal in mind in the American Recovery and Reinvestment Act of 2009 alone. ${ }^{4}$ Second, since more people are unemployed at these times, government spending on social-insurance and income-support programs increases. Raising money through taxes to fund Keynesian job-creation efforts and increased payments to unemployed workers, however, distorts incentives to work and save. ${ }^{5}$ This Article argues that, instead of incurring these inefficiencies to increase employment during recessions, in some cases it is more efficient to incur other, but smaller, inefficiencies-in particular, reorganizing rather than liquidating some firms that are more valuable to creditors and owners liquidated. Yes, doing so would reduce returns to creditors and make it less likely that creditors will invest, thereby harming businesses. But preserving jobs through bankruptcy law can sometimes avoid reducing incentives to work and save-a potentially larger inefficiency caused by tax increases to pay for employmentincreasing government spending.

If taxes were not distortionary, bankruptcy law ideally would not seek to sustain employment, since tax-funded spending could do so without causing distortion. But in a "second-best" world, where there is already at least one distortion, adding a second distortion does not necessarily increase, and can in fact decrease, the total amount of distortion. ${ }^{6}$ This Article applies such reasoning, suggesting that bankruptcy law can create an additional distortion by considering employment effects but nonetheless reduce the distortion overall by reducing the distortion from taxation. The Article proposes that bankruptcy law weigh two concerns:

2. N. Gregory Mankiw, Macroeconomics 262-64 (5th ed. 2003) [hereinafter Mankiw, Macroeconomics].

3. See, e.g., American Recovery and Reinvestment Act of 2009, Pub. L. No. 111-5, 123 Stat. 115 (codified in scattered titles of U.S.C. (2012)).

4. James Freeman, Editorial, Obama's Stimulus, Five Years Later, Wall St. J. (Feb. 17, 2015), www.wsj.com/articles/SB10001424052702303945704579387692278347858 (on file with the Columbia Law Review). Prior work suggests that it costs $\$ 26,000$ to create or save a job-and this is on the low end of estimates. See Gabriel Chodorow-Reich et al., Does State Fiscal Relief During Recessions Increase Employment? Evidence from the American Recovery and Reinvestment Act, 4 Am. Econ. J.: Econ. Pol'y 118, 137 (2012). The Obama Administration itself estimates that it spent $\$ 125,000$ per job. Council of Econ. Advisers, Exec. Office of the President, The Economic Impact of the American Recovery and Reinvestment Act Five Years Later: Final Report to Congress 3, 10 tbl.3 (2014), www.whitehouse.gov/sites/default/files/docs/cea_arra_report.pdf [http://perma.cc/29JD-BN8M].

5. See Charles L. Ballard et al., General Equilibrium Computations of the Marginal Welfare Costs of Taxes in the United States, 75 Am. Econ. Rev. 128, 132-33 (1985).

6. R.G. Lipsey \& Kelvin Lancaster, The General Theory of Second Best, 24 Rev. Econ. Stud. 11, 12 (1956). 
(1) the costs to creditors and businesses from preserving jobs through bankruptcy and (2) the taxes necessary to fund programs that promote employment. On the one hand, if-with the goal of preserving jobsbankruptcy courts do not maximize the return to creditors, creditors will lose more money. Furthermore, future creditors, knowing that courts will do this, will be less likely to lend to businesses, which will suffer correspondingly. One can think of the distortion to lending caused by courts' consideration of job preservation as an "employment preservation tax"7 on creditors. On the other hand, if bankruptcy courts do not seek to preserve jobs during recessions, a government seeking to maintain employment will face increased expenditures on socialinsurance and employment-stimulus programs, which means that the government must at some point raise taxes to fund those obligations. These taxes reduce work and investment and make the economy worse off. The fact that the government must raise funds through distortionary taxes means that even "nonideal" policies may be best when they coexist with other policies like distortionary taxes.

This Article first proposes "counter-cyclical bankruptcy rules" that calibrate how much bankruptcy judges consider the employment effects of a bankruptcy proceeding based on where the economy is in the business cycle. If labor markets are working properly and unemployment rates are low, then the bankruptcy judge should not consider employment effects and instead focus on maximizing return to creditors. If labor markets are not working properly and unemployment rates are high (so that a job saved at a reorganized firm is likely to lead to a reduced unemployment rate), then the bankruptcy judge should return less to creditors in some cases, thereby saving jobs and, in turn, saving the government money. The rules this Article proposes have substantial scope for affecting employment and efficiency by way of preserving through bankruptcy both fewer jobs during times of low unemployment and more jobs during times of high unemployment: From 1980 through 2012, there were over 1.7 million business bankruptcy filings, ${ }^{8}$ and approximately 1,000 were large, publicly traded corporations that employed over 7.4 million workers before their filings. ${ }^{9}$

7. See Professors Thomas Jackson and David Skeel add that promoting economic recovery through the appropriate allocation of capital is another benefit of maximizing the value to creditors. Thomas H. Jackson \& David A. Skeel, Jr., Bankruptcy and Economic Recovery 17-20 (Univ. Pa. Law Sch. Inst. for Law \& Econ., Research Paper No. 13-27, 2013), http://ssrn.com/abstract=2306138 (on file with the Columbia Law Review).

8. The source of the data for this calculation is Am. Bankr. Inst., Annual Business and Non-Business Filings by Year (1980-2015), http://www.abi.org/newsroom/ bankruptcy-statistics (follow "Annual and Non-business Filings by Year (1998-2015)" hyperlink) (on file with the Columbia Law Review).

9. Those reorganized had at least 2.6 million employees after reorganization. UCLA-LoPucki Bankruptcy Research Database, UCLA Sch. of Law, Cases Table (on file with the Columbia Law Review) (database updated Mar. 10, 2016). 
This Article arrives at a kind of midpoint in the debate over the extent to which bankruptcy law should consider "community concerns" beyond the interests of the firm's owners and creditors, such as those of employees, customers, suppliers, and the local community. ${ }^{10}$ Legislative history suggests that Congress intended for the bankruptcy process to support employment. ${ }^{11}$ "Traditionalist" bankruptcy scholars like Professor Elizabeth Warren have argued bankruptcy should consider community concerns. ${ }^{12}$ In recent decades, though, efficiency-minded law and economics scholars have questioned this emphasis. These "proceduralists" suggest that bankruptcy should maximize the return to creditors and shareholders. ${ }^{13}$ This Article assumes the normative goal of efficiency but finds that pursuing efficiency sometimes supports the argument that bankruptcy should consider employment effects. It also provides support for positions taken by some academics for why the bankruptcy process should consider community concerns.

10. See Elizabeth Warren, Bankruptcy Policy, 54 U. Chi. L. Rev. 775, 788 (1987) (arguing that bankruptcy law should have a variety of goals, including community interests); see also Karen Gross, Failure and Forgiveness: Rebalancing the Bankruptcy System 8 (1997) (arguing for inclusion of community interests in the bankruptcy system); Donald R. Korobkin, Rehabilitating Values: A Jurisprudence of Bankruptcy, 91 Colum. L. Rev. 717, 720-21 (1991); cf. Douglas Baird, Loss Distribution, Forum Shopping, and Bankruptcy: A Reply to Warren, 54 U. Chi. L. Rev. 815, 824-26 (1987) (arguing bankruptcy policy should maximize returns to creditors). This Article supports some elements of the argument of Professor Elizabeth Warren in this famous debate with Professor Douglas Baird.

11. When it introduced the current Chapter 11 in 1977, the House Judiciary Committee wrote in its report that:

The purpose of a business reorganization case ... is to restructure a business's finances so that it may continue to operate, provide its employees with jobs, pay its creditors, and produce a return for its stockholders .... It is more economically efficient to reorganize than to liquidate, because it preserves jobs and assets.

H.R. Rep. No. 95-595, at 220 (1977) (emphasis added). This language has been cited by the Supreme Court to mean that " $\mathrm{t}] \mathrm{h}$ he fundamental purpose of reorganization is to prevent a debtor from going into liquidation, with an attendant loss of jobs and possible misuse of economic resources." NLRB v. Bildisco \& Bildisco, 465 U.S. 513, 528 (1984). The Court also said that bankruptcy courts should "balanc[e] the interests of the affected parties-the debtor, creditors, and employees ... [including] any qualitative differences between the types of hardship each may face." Id. at 527. Citing the same language, the Court in United States v. Whiting Pools, Inc. said that, "[b]y permitting reorganization, Congress anticipated that the business would continue to provide jobs, to satisfy creditors' claims, and to produce a return for its owners." 462 U.S. 198, 203 (1983).

12. Jeff Ferriell \& Edward J. Janger, Understanding Bankruptcy § 1.02 (2013) ("A key difference between the proceduralists and the traditionalists concerns whether bankruptcy should be used to advance goals of stakeholders other than creditors."); Warren, supra note 10, at 788-93 (arguing that bankruptcy law should seek to promote broader community and distributive interests).

13. See, e.g., Ferriell \& Janger, supra note $12, \S 1.02$ ("[B]ankruptcy should do nothing more than preserve value for creditors by seeking to eliminate the inefficiencies that are inherent in atomistic state collection proceedings."); Baird, supra note 10, at 822-24 (arguing that bankruptcy policy should seek to maximize returns to creditors). 
This Article does not take a position on whether bankruptcy law should consider employment effects more or less than it already does overall but rather proposes what bankruptcy law should target when it does so. In particular, this Article offers a method and the relevant data for implementing a simple cost-benefit rule that constrains the current ad hoc judicial discretion exercised in considering employment effects. Many law and economics scholars of bankruptcy law believe there is a "pro-reorganization" or "procontinuation bias" in bankruptcy law as it stands. ${ }^{14}$ This Article argues that when unemployment is high, this tendency toward reorganization, consistent with apparent congressional intent, is appropriate; a job saved in bankruptcy will increase overall employment, reduce hardship for workers, and save the government money.

This Article proceeds as follows. Part I situates this Article in the debate between the "traditionalists" and "proceduralists" in bankruptcy law and also, more broadly, in the debate about "efficient" legal rules. Part II develops an efficiency-based normative framework for assessing when bankruptcy judges should take into account the employment effects of bankruptcy. Part III explains how these rules could be implemented in practice. Part IV gives an example calculation of how a bankruptcy judge could evaluate the benefits of preserving jobs through reorganization. Part V responds to potential critiques.

\section{EFFICIENT BANKRUPTCY LAW AND EFFICIENT LEGAL RULES}

\section{A. The Broader Debate About Efficient Legal Rules}

The debate over whether bankruptcy should aim to maximize shareholder and creditor returns is part of the broader debate over whether legal rules or taxes (or, in this case, tax-funded programs) should be used to achieve social goals. ${ }^{15}$ Taxes distort behavior, reducing incentives to

14. See Edward R. Morrison, Bankruptcy Decision Making: An Empirical Study of Continuation Bias in Small-Business Bankruptcies, 50 J.L. \& Econ. 381, 392-411 (2007) (describing the conventional view of continuation bias and showing evidence inconsistent with that view in a sample of Illinois bankruptcies). For other accounts arguing that there is a procontinuation bias, see Julian R. Franks \& Walter N. Torous, A Comparison of the U.K. and U.S. Bankruptcy Codes, 6 J. Applied Corp. Fin. 95, 101 (1993) (arguing that the U.S. bankruptcy system is systematically prodebtor because it has "strong incentives to maintain the firm as a going concern even when it is worth more in liquidation"); Lynn M. LoPucki, The Debtor in Full Control-Systems Failure Under Chapter 11 of the Bankruptcy Code?, 57 Am. Bankr. L.J. 99, 106-07 (1983) (noting that, under former version of Chapter 11, bankruptcy prcoeedings could not be for the sole purpose of liquidation).

15. The debate has largely been framed in terms of "redistribution," but the choice is equally relevant here. Important articles in the debate are Louis Kaplow \& Steven Shavell, Why the Legal System Is Less Efficient than the Income Tax in Redistributing Income, 23 J. Legal Stud. 667, 674-76 (1994) (arguing that legal rules should be "efficient," and all redistribution should take place through the income tax) and Chris William Sanchirico, 
invest and work, thereby wasting about $\$ 0.33$ with each marginal dollar raised.$^{16}$ However, by the "one-third rule," if deviating from an "efficient" legal rule results in a distortion that costs less than one-third of the amount of money that no longer needs to be raised through taxes, then a court should adopt that deviation. ${ }^{17}$ Indeed, that is the efficient legal rule. Using terminology developed in other work, this Article argues that what some might consider an "efficient" bankruptcy rule-maximizing return to shareholders-is actually merely an "i-efficient" legal rule. ${ }^{18}$ That is, it is efficient only internally to the relations between firms and their creditors, investors, and other parties that underlie bankruptcy law. But it is not efficient considering the global effects of the rule, such as placing unemployed workers on programs for which taxpayers pay. This Article takes as its goal global efficiency, defined as the wealth produced by the entire economy, including the costs of other spending and tax programs impacted by legal rules the bankruptcy system has adopted.

\section{B. "Community Concerns": "Proceduralists" Versus "Traditionalists" in Bankruptcy Law}

The debate in bankruptcy law about "efficiency" has been between "traditionalists," who support consideration of "community concerns," 19 and "proceduralists," who want bankruptcy law to maximize the value of the assets leaving bankruptcy. The traditionalists, in part, point to congressional language that indicates promoting employment was a goal of bankruptcy law. ${ }^{20}$ Indeed, the Supreme Court has found that there is a "congressional goal of encouraging reorganizations."21 So the traditionalists argue that bankruptcy judges should act to preserve employment in the name of these broad non-efficiency-based criteria.

Taxes Versus Legal Rules as Instruments for Equity: A More Equitable View, 29 J. Legal Stud. 797, 805-06 (2000) (arguing that it can be efficient to redistribute through legal rules).

16. See Ballard et al., supra note 5, at 135 (finding that marginal welfare cost from raising a dollar of tax revenue is $\$ 0.33$, assuming a savings elasticity of 0.4 and a labor supply elasticity of 0.15 ).

17. Zachary Liscow, Note, Reducing Inequality on the Cheap: When Legal Rule Design Should Incorporate Equity as Well as Efficiency, 123 Yale L.J. 2478, 2482-83 (2014).

18. Id. at 2483, 2487 (defining an i-efficient rule as a "rule that is efficient (i.e., wealth-maximizing based on individuals' willingness to pay) in the narrow 'internal-tolegal-rule' context").

19. "Community concerns" are conceptually distinct from the idea of shareholder representation in corporate governance. This Article proposes a remedial, not a structural, point.

20. See supra notes 10-12 and accompanying text (discussing bankruptcy law traditionalists).

21. United States v. Whiting Pools, Inc., 462 U.S. 198, 204 (1983) (finding that property seized by the IRS prior to filing a reorganization petition must be turned over to the debtor under 11 U.S.C. $\$ 542$ (a) (2012) and relying on congressional intent as evinced in legislative history, H.R. Rep. No. 95-595, at 367-68 (1977); S. Rep. No. 95-989, at 82 (1978)). 
In contrast, the proceduralists argue that bankruptcy law should maximize the value of the firm exiting bankruptcy. They have argued that there has traditionally been a pro-reorganization or procontinuation bias relative to the efficient baseline. ${ }^{22}$ They point to the same Supreme Court cases and legislative history cited by the traditionalists as evidence of that bias. Law and economics scholars have argued that several bankruptcy rules lead to an inefficient procontinuation bias. ${ }^{23}$ For example, Professors Yeon-Koo Che and Alan Schwartz argue that the prohibition in $\S 365$ (e)(1)(A) of the Bankruptcy Code on "ipso facto clauses," which excuse the solvent party from performance of a contract when the other party becomes insolvent, is inefficient. ${ }^{24}$

This Article does not claim that there should be more reorganizations relative to the status quo but rather that courts should time properly over the business cycle those reorganizations driven by a concern for employment. When applying the normative framework of the proceduralists (i.e., pursuing efficiency), there should be some concern for employment. Moreover, this concern should be considered within the context of the economy's current place within the business cycle. ${ }^{25}$ This Article is actually largely supportive of the law and economics literature criticizing procontinuation policies. It supports counter-cyclical and contextdependent employment-sustaining decisions rather than rules with a consistent procontinuation bias like ipso facto clauses that are "baked in" to bankruptcy law ${ }^{26}$ and that effectively "juice" the firm at the expense of creditors at all times.

\section{MODEL OF BANKRUPTCY AND EMPLOYMENT}

\section{A. Background Macroeconomic Literature}

This Article is also part of a small, but growing, literature on how law should respond to macroeconomic concerns. For example, Professor Yair Listokin makes a forceful argument that the lack of macroeconomic considerations in tax law is quite problematic. ${ }^{27}$ In another example of this

22. See supra note 14 .

23. See Yeon-Koo Che \& Alan Schwartz, Section 365, Mandatory Bankruptcy Rules and Inefficient Continuance, 15 J.L. Econ. \& Org. 441, 462 (1999) (arguing that the prohibition in $\S 365$ (e)(1)(A) of the Bankruptcy Code on ipso facto clauses is inefficient and may lead to firms continuing inefficient projects). Legislative history here supports the goal of reorganization. The Senate Report on the section says that the presence of ipso facto clauses "frequently hampers rehabilitation efforts." S. Rep. No. 95-989, at 59.

24. Che \& Schwartz, supa note 23 , at 462.

25. Since the normative framework is efficiency, issues of fairness do not come into play for those who have the bad luck of being creditors to a business that goes bankrupt during a time of high unemployment and therefore receive less under counter-cyclical bankruptcy rules.

26. See Che \& Schwartz, supra note 23, at 442.

27. See Yair Listokin, Equity, Efficiency, and Stability: The Importance of Macroeconomics for Evaluating Income Tax Policy, 29 Yale J. Reg. 45, 49-50 (2012). 
emerging literature, this author has drawn two counterintuitive conclusions about how taxes should change during recessions: To increase employment and ensure that those who most need jobs get them, tax cuts should favor employers, not employees, and the government should encourage marginal workers to leave the labor force by subsidizing nonemployment. ${ }^{28}$ Finally, although not primarily focused on how varying macroeconomic conditions should affect the law, Professors Jonathan Masur and Eric Posner discuss how cost-benefit analysis could take into account regulations' effects on employment. ${ }^{29}$ This is the first paper that asks how bankruptcy should respond to macroeconomic concerns and the first to suggest how courts could take into account such concerns.

This Article relies on an understanding of the economy and labor markets that differs from the traditional model in law and economics, which typically assumes that labor markets are "neoclassical." In neoclassical labor markets, prices (e.g., wages) adjust so that supply equals demand.$^{30}$ There are no "frictions" in finding new jobs; that is, it does not take time or effort for an employer and an employee to find each other. Under these circumstances, it would be pointless to preserve firms with liquidation value greater than reorganization value. This would penalize creditors without improving circumstances for workers as a whole. Laid-off workers would simply immediately find new jobs. Some may have lower wages because their skills are no longer in as much demand, but there is no efficiency reason to keep them employed in their previous jobs. No market failure justifies deviating from the outcome that maximizes the value of the firm, and no positive externality results from keeping a worker in the job. ${ }^{31}$

28. Zachary Liscow \& William Gui Woolston, How Income Taxes Should Change During Recessions, 70 Tax L. Rev. (forthcoming 2017) (on file with the Columbia Law Review). The intuition for the result is as follows: If recessions effectively result in a wage floor and therefore rationing of a fixed number of jobs, then subsidizing employers will create more jobs, while subsidizing employees will draw more marginal workers into the labor force without creating more jobs, making those who really need jobs compete with those who receive little surplus from working. By similar reasoning, subsidizing nonemployment draws marginal workers out of the labor force, making it easier for those who place a high value on attaining employment to get one of the fixed number of jobs available. Id. (manuscript at 4).

29. See Jonathan S. Masur \& Eric A. Posner, Regulation, Unemployment, and CostBenefit Analysis, 98 Va. L. Rev. 579, 582 (2012) (arguing that cost-benefit analysis should consider employment effects).

30. See Neva Goodwin et al., Principles of Economics in Context 219-21 (Routledge 2015) (2014) (describing the market-clearing mechanism of labor markets under neoclassical model).

31. In neoclassical labor markets, there may be individuals who are unwilling to work for the market wage. Those persons exit the labor force. See id. (describing neoclassical labor markets generally). The key difference between neoclassical labor markets and those considered here is that there is a set of workers who would be willing to work at the prevailing wage but are unable to find a job. There is an excess supply of workers, which 
This Article builds on insights from macroeconomics showing that departing from these neoclassical assumptions reverses these conclusions. ${ }^{32}$ Although no specific model is required for the results here, these macroeconomics models provide useful conceptual frameworks for understanding how the results might arise. In general, bankruptcy serves the important function of reallocating capital and labor to more productive uses. ${ }^{33}$ But this result does not necessarily apply in recessions. Whether due to sticky information, ${ }^{34}$ sticky wages, ${ }^{35}$ or some other cause, reallocation does not work as well during recessions. Capital is underutilized. Workers lose their jobs and then become unemployed; they are not reallocated. One way to understand this phenomenon is through the presence of sticky wages. Labor demand falls, but wages do not. As a result, when workers are laid off, they are not re-employed. The economy stays in a recession, so capital too is underutilized. This market failure may justify "interference" with the value-maximizing role of bankruptcy.

Two positive externalities result from keeping workers employed. First, the government does not have to incur spending on items like unemployment insurance required for unemployed workers; due to long unemployment durations, this spending is unusually high during recessions for each job lost. ${ }^{36}$ Second, as John Maynard Keynes argued in the first half of the twentieth century, keeping one worker employed results in a "multiplier," through which increased spending by one employed worker results in more employment, further increasing spending and therefore employment. ${ }^{37}$ Thus, spending a dollar to keep a worker employed is worth more than a dollar in increased economic output. ${ }^{38}$

does not happen in neoclassical labor markets because the wage decreases until enough workers have exited the labor force to equilibrate the supply and demand of workers.

32. See infra notes 34-35 (describing how sticky information or sticky wages can impact reallocation).

33. See Jackson \& Skeel, supra note 7, at 5-6 (explaining the effectiveness of bankruptcy law at reallocating assets to productive uses); see also Lucia Foster, John Haltiwanger \& C. J. Krizan, Market Selection, Reallocation and Restructuring in the U.S. Retail Trade Sector in the 1990s, 88 Rev. Econ. \& Stat. 748, 748-49 (2006) (noting the importance and dynamics of reallocation).

34. See N. Gregory Mankiw \& Ricardo Reis, Sticky Information Versus Sticky Prices: A Proposal to Replace the New Keynesian Phillips Curve, 117 Q.J. Econ. 1295, 1296 (2002) (introducing the sticky-information model).

35. Sticky wages are traditionally assumed in the Keynesian model. See David Romer, Advanced Macroeconomics 242-44 (3d ed. 2006) (presenting a modern rendition of the Keynesian model).

36. Henry S. Farber, Job Loss in the Great Recession: Historical Perspective from the Displaced Workers Survey, 1984-2010, at 1-2 (IZA, Discussion Paper No. 5696, 2011) (on file with the Columbia Law Review) (noting the length of unemployment duration).

37. See Mankiw, Macroeconomics, supra note 2, at 262-64 (illustrating how government purchases cause a "multiplier").

38. Note that Keynesian views, though widely held among economists, are not universally held. See, e.g., Robert J. Barro, Opinion, Government Spending Is No Free Lunch, 
This effect does not occur during times of low unemployment. At times and places of "low" unemployment, there are still unemployed workers. When a liquidated firm then lays off workers, they will still be unemployed for some period of time. However, this "frictional" employment results in what economists call the "natural rate of unemployment," defined as the level of unemployment resulting from job-matching frictions in "normal" times, when the economy is neither stressed nor overheated. ${ }^{39}$ It ought not be addressed through bankruptcy law because there is little reason to think that preserving the jobs in a bankrupt firm would actually increase overall employment: That frictional employment is to a large extent inevitable, and preserving more jobs at bankrupt firms would do little to reduce it. ${ }^{40}$ Rather, without the Keynesian multiplier that results when the economy is operating below its normal capacity and employment is above the natural rate, it is not worth the loss to creditors and the distortion to creditor behavior that results from preserving jobs at the expense of creditors. That distortion itself is likely to reduce employment. For the same reason, there are costs to having employment protections that make it difficult to lay off workers, as such protections may actually increase unemployment. ${ }^{41}$

A separate issue in deciding when and where bankruptcy law should consider employment is whether it ought to consider employment in places of high unemployment when the national unemployment rate is low. This is an interesting question, but one that is beyond the scope of this Article, since the underlying economic causes of the localized unemployment are less clear. This Article will examine the presence of temporarily high unemployment rates in certain locations as a reason to consider employment effects more strongly, but it will use an elevated national unemployment as the trigger for purposes of counter-cyclical bankruptcy rules.

\section{B. Basic Setup}

To understand how to implement counter-cyclical bankruptcy rules, compare the costs and benefits of preserving a job through reorganization instead of liquidation in bankruptcy. ${ }^{42}$ The first key variable is the

Wall St. J. (Jan. 22, 2009), http://www.wsj.com/articles/SB123258618204604599 (on file with the Columbia Law Review).

39. See Mankiw, Macroeconomics, supra note 2 at 155-58, 175 (defining the natural rate of unemployment).

40. See id. at 159 ("Some frictional unemployment is inevitable in a changing economy.").

41. See, e.g., Daron Acemoglu \& Joshua D. Angrist, Consequences of Employment Protection? The Case of the Americans with Disabilities Act, $109 \mathrm{~J}$. Pol. Econ. 915, 917, 929-32 (2001) (using the Americans with Disabilities Act to show that employment protections, at least in this context, can increase unemployment for the affected group).

42. This analysis considers only a binary choice between liquidation and reorganization. It does not consider the possibility that preserving some jobs in a firm may be 
average cost of preserving a job for a year (a "job-year") through bankruptcy $(C)$, which this Article defines as the difference between the liquidation value $(L)$ and the reorganization value $(R)$ of a firm, divided by the number of job-years in the economy preserved by reorganizing instead of liquidating $(W) \cdot{ }^{43}$ To be clear, both $L$ and $R$ consider only the return to creditors and, if relevant, equity. Thus,

$$
C=\frac{L-R}{W}
$$

In some bankruptcies $C$ will be large, either because of the large difference between liquidation and reorganization value or because of the small number of workers whose jobs are preserved. In other bankruptcies $C$ will be small, either because of a small difference between liquidation and reorganization value or because a large number of workers' jobs are preserved. The key concern for a bankruptcy judge or policymaker is the level of $C$ below which firms should be reorganized despite the loss to creditors. Law and economics scholars have generally argued that whenever $C$ is greater than 0 , the firm should be liquidated.

In deciding on this threshold level of $C$, some government actor-a bankruptcy judge or otherwise-should compare the efficiency cost of the loss to creditors with the benefits of preserving employment for $W$ workers. Presented below are two methods for measuring the benefits of preserving employment.

\section{Two Methods for Estimating the Value of Maintaining Employment}

1. Method One: The Shadow Value of Maintaining Employment. - The first method for estimating the value of a saved job uses the "shadow value" of a job that is implied by the amount the government recently spent to maintain employment. ${ }^{44}$ That is, a way to determine the value to the government of maintaining employment is to see how much it actually spent to do just that. Presumably the government would take into account all benefits-aggregate stimulus, increased tax payments, avoided social-insurance and income-support payments, and anything else that members of Congress believe is important to their constituents. The analysis here focuses on the value of preserving a job during the Great Recession through the American Reinvestment and Recovery Act. Estimates of the amount that the government spent to preserve a job vary

cheaper than preserving other jobs, which could lead to conclusions like partial reorganizations.

43. $W$ is based on the employment after reorganization, not before, which is important since reorganizations often result in layoffs.

44. One paper taking a similar approach is Orley Ashenfelter \& Michael Greenstone, Using Mandated Speed Limits to Measure the Value of a Statistical Life, 112 J. Pol. Econ. 226, 227 (2004) (using the preferences revealed by speed limits adopted by political processes to measure the value of a statistical life). 
widely, from an estimate of $\$ 26,000,{ }^{45}$ up to the Administration's own estimate of $\$ 125,000,{ }^{46}$ and congressional Republicans' estimates of an infinite cost. ${ }^{47}$ This analysis implicitly makes two rather heroic assumptions: first, that the government was optimizing; second, that it knew (or had a good guess about) the cost of its actions. Nevertheless, the government's best guess in 2009 may be the best guess now. Since the Administration's estimate of $\$ 125,000$ to maintain a job-year is the official estimate and is rather high (despite the Administration's incentives to make it seem low), this Article will use this figure as a baseline assumption.

By this calculation, a firm should be reorganized when the efficiency cost resulting from paying less to creditors is less than the efficiency cost resulting from $G$, the government spending to create or preserve a job for a year. That is, a firm should be reorganized when:

$$
\text { Efficiency } \cos t\left(\frac{L-R}{W}\right)<\text { Efficiency } \operatorname{Cos} t(G)
$$

Taking the right-hand side of the inequality first, the efficiency cost of government spending to create a job-year is equal to (a) the gross cost of raising a dollar of government funds minus (b) the social value of the spending (of course, beyond the benefits of job preservation, which are present on both sides of the inequality). The gross cost of raising a dollar to preserve a job is a well-studied concept in economics, known as the marginal cost of public funds (MCPF) ${ }^{48}$ which is equal to the extra dollar raised plus the distortion to working and investing that results from raising that dollar of revenue. Then the social value of the good (e.g., a road), service (e.g., medical care), or transfer payment (e.g., Social Security payment) provided must be subtracted from the MCPF to find the efficiency cost. This Article defines $\operatorname{Value}(G)$ as the value of public spending, ignoring the benefits of job preservation. Thus, the relevant comparison is that a firm should be reorganized when:

$$
\text { Efficiency cost }\left(\frac{L-R}{W}\right)<M C P F(G)-\operatorname{Value}(G)
$$

45. Chodorow-Reich et al., supra note 4, at 137.

46. The Council of Economic Advisers published a report stating that the Recovery Act saved or created an average of 1.6 million jobs a year for four years, produced by about $\$ 800$ billion in spending through the end of 2013. Council of Econ. Advisers, supra note 4 , at 10 tbl.3. Dividing $\$ 800$ billion by the the product of 4 and 1.6 million yields $\$ 125,000$ per job-year. For simplicity, this calculation ignores discounting.

47. See Did the Stimulus Create Jobs?, FactCheck.org (Sept. 27, 2010), www.factcheck.org/ 2010/09/did-the-stimulus-createjobs [http://perma.cc/9TT8-RD67] (quoting Republican candidates who claim that the economic stimulus package did not create or save any jobs). The claim that the Recovery Act saved or created zero jobs amounts to a claim of an infinite cost, since dividing cost by the number of jobs created or saved is infinite if the claimed number of jobs is zero.

48. See, e.g., Alan J. Auerbach \& James R. Hines Jr., Taxation and Economic Efficiency, in 3 Handbook of Public Economics 1347, 1385 (Alan J. Auerbach \& Martin Feldstein eds., 2002). 
Turning to the left-hand side of the inequality, the efficiency cost arising from the reduced payments to the creditors comes from two components. First, future creditors are less likely to lend to businesses since they know that they may lose out if there is a bankruptcy, harming businesses and causing another distortion.$^{49}$ But second, the creditors in the bankruptcy at hand get less money. That money is lost to the world. That is, there is a crucial difference between the efficiency cost of reorganizing a firm that is worth more when liquidated and taxing to pay for job creation. In the case of an "inefficient" reorganization, no equivalent public good, service, or transfer is provided. Assets are simply deployed in a manner that reduces returns to creditors-pure deadweight loss (again, ignoring the benefits of job gains, which government spending also produces). Hence, no equivalent of the value of government spending should be subtracted from the cost to creditors. Therefore, because there is no offsetting gain from spending apart from the employment benefits, the efficiency cost of the "inefficient" reorganization is the full cost of the financial loss to creditors plus the cost of the distortion to their behavior.

To implement the rule in practice, these values need to be estimated. As noted earlier, the MCPF is a well-studied estimate. The best estimate is that it costs society about $\$ 1.33$ for the government to raise a dollar of revenue. ${ }^{50}$ Estimating Value $(G)$ is more difficult, since the spending could take many forms. Determining the value of government transfers is easy: The value of a lump-sum payment to an individual of one dollar is simply one dollar (again, ignoring any employment-creating benefits). Assessing the value of a road is harder; it could range from zero dollars for a "road to nowhere" to more than a dollar for a valuable public good. ${ }^{51}$ This Article conservatively assumes as an illustrative baseline that the value of a dollar of government spending is a dollar, since this is true for at least the large portion of government stimulus spending used for tax rebates.

Estimating the left-hand side of the equation involves somewhat more guesswork. The efficiency cost of changing firms' investment behavior ex ante in anticipation of lower returns upon bankruptcy is not well known. ${ }^{52}$ However, these lower returns are essentially an expected tax on

49. Note that this distortion would likely be somewhat mitigated by the reduced wages that employers could pay to employees with counter-cyclical bankruptcy rules. Since workers would value the increased insurance over keeping their jobs in recessions, they would demand lower wages, making businesses more profitable and making creditors more willing to lend.

50. Ballard et al., supra note 5 , at $135 \&$ tbl.3 (estimating a marginal excess burden of $\$ 0.33$ per additional dollar of tax revenue raised, for a total cost of $\$ 1.33$ to society).

51. Presumably, though, roads of sufficient value would have been built before the recession.

52. Indeed, the effects could be heterogeneous, as they differentially affect different types of creditors, investors, and borrowers. In the lead up to a potential recession, this proposal could tighten credit to firms at risk of bankruptcy because the proposal would 
creditors. Though the ratio of the creditor distortion to the MCPF will be part of a parameter in the formula, as a baseline illustration, assume for simplicity that the "tax" resulting from paying less back to firms is equal to the MCPF, which incorporates the financial loss to creditors and the resulting distortion to their behavior.

In this Article, $\alpha$ represents the ratio of the distortion from general taxation (i.e., the MCPF minus the value of government spending) to the distortion from the "tax" on creditors. In general, then, a firm should be reorganized when

$$
\frac{L-R}{W}<\alpha G
$$

Under the illustrative assumptions used here, $\alpha=0.25 .^{53}$

The next step to understanding when a firm should be reorganized is to determine $W$, the number of job-years of employment that results from preserving a firm. Two types of jobs can be preserved: direct and indirect jobs. Direct jobs are those directly saved at the firm (and its competitors). Indirect jobs are those that result from the Keynesian multiplier, whereby those employed consume goods and services, resulting in additional employment.

To measure the direct employment effects of a layoff, one must consider at least two ancillary effects. First, more workers may be hired elsewhere as the products that would have been sold by the liquidated firm are produced elsewhere. Second, laid-off workers compete with other unemployed workers for a limited number of jobs, making it harder for those other unemployed workers to get jobs. Assume as a baseline that these two effects just offset each other, so that the number of jobs saved at a firm is a good approximation of the total direct jobs created in the economy. This assumption will be valid in some contexts but not in others. For example, if the firm went bankrupt due to foreign competition, then at least in the short run few American workers may be hired as a result, since foreign producers would be picking up the slack. In that case, the true total effect on unemployment may be underestimated, because the laid-off workers from the bankrupt firm would be competing

reduce expected payouts from those firms to creditors in the case of bankruptcy. Such an impact might reduce the extent to which bankruptcy judges should seek to reorganize rather than liquidate firms in the name of preserving employment because tightening credit could worsen a recession.

53. The reason is that Efficiency $\operatorname{cost}\left(\frac{L-R}{W}\right)<M C P F(G)-\operatorname{Value}(G)$ implies, following the argument above, that $M C P F\left(\frac{L-R}{w}\right)<M C P F(G)-\operatorname{Value}(G)$. Consider that it costs $\$ 1.33$ to transfer a dollar of government-raised money, which has a dollar of non-job-related benefits, while (by assumption) it costs $\$ 1.33$ to transfer a dollar from creditors, which has no non-job-related benefits. Thus, $M C P F\left(\frac{L-R}{w}\right)<M C P F(G)-$ Value $(G)$ implies that $1.33 \frac{L-R}{w}<$ $1.33 G-G$. Rearranging and simplifying yields $\frac{L-R}{w}<0.25 G$. Thus, $\alpha=0.25$. Put differently, the ratio of costs from raising a dollar of government-raised money compared to raising a dollar through transferring one from creditors is $(1.33-1) /(1.33)=0.25$. 
with and increasing the unemployment rate for existing unemployed workers without the bankruptcy creating any new jobs at other American producers.

The number of direct jobs preserved then must be converted into a number of direct job-years preserved, since some employees quickly find jobs and others do not. The way to estimate the total effect on unemployment is to follow laid-off workers and see how long they stay unemployed. ${ }^{54}$ Ideally, one would estimate time to re-employment for workers laid off due to bankruptcy, since workers laid off under such circumstances may stay unemployed for longer than those let go for other reasons. Workers laid off due to bankruptcy may be unemployed for longer, both because their skills are less likely to be in demand and because the local labor market may be glutted with unemployed workers; alternatively, they may be unemployed for a shorter period of time because the layoffs are less likely to be tied to poor performance. The best available evidence, though, is on "displaced" workers-that is, those laid off because their plant or company closed or moved, their position or shift was abolished, there was insufficient work, or a similar reason..$^{55}$ Work by labor economist Henry Farber shows that workers laid off during the Great Recession had an average unemployment duration after layoff of at least fifty weeks; many workers laid off then still had not been re-employed when they were surveyed years later. ${ }^{56}$ The Article labels as $l$ the average unemployment duration avoided by directly preserving a job through reorganization.

The indirect employment effects then need to be added to these direct employment effects. Prior work estimates the size of this Keynesian "multiplier" during the Great Recession to be around two. ${ }^{57}$ That is, every worker directly employed results in another worker indirectly employed. The number of workers directly employed as a result of reorganizing instead of liquidating is denoted $D$ and the multiplier is

54. Labor economists calculate this using the Kaplan-Meier survival curve. See Bruce D. Meyer, Unemployment Insurance and Unemployment Spells, 58 Econometrica 757, 762-66 (1990) (applying the Kaplan-Meier survival curve to unemployment).

55. Farber, supra note 36 . This analysis constructs this estimate of fifty weeks as follows: Farber shows that $43.7 \%$ of workers had been re-employed by the time of the survey; they had an average unemployment duration of 13.4 weeks. Id. at 37-38 app. at tbls.10 \& 12. The remaining $56.3 \%$ of workers were not reemployed at the time of the survey. Id. at 37 app. at tbl.10. Since the survey asked if workers had been laid off over the previous three years, the approximate average unemployment duration of these workers is 1.5 years. Of course, this is a substantial underestimate of the true duration of unemployment, since this account does not count any unemployment after the date of the survey. Weighting 13.4 weeks and 1.5 years by the appropriate fractions yields an average unemployment duration after displacement of 49.8 weeks.

56. See supra note 55 and accompanying text. Note that "unemployed" includes those who exit the labor market, which is not the customary way of counting those who exit labor markets.

57. See, e.g., Chodorow-Reich et al., supra note 4, at 138. 
denoted $m$. Estimates of the effect of government spending on employment already include the indirect jobs, so no multiplier should be added to the government spending side of the equation. Accordingly, a firm should be reorganized when

$$
\frac{L-R}{D l m}<\alpha G,
$$

or

$$
\frac{L-R}{D}<\alpha \operatorname{lm} G \equiv J
$$

where $J$ is the value of preserving a direct job at a firm through reorganization. That is, a firm should be reorganized when the cost of preserving a job there $\left(\frac{L-R}{D}\right)$ is less than the value of persving a job there (J).

Using the baseline set of assumptions that (1) "taxing" creditors and taxpayers yields the same distortion; (2) a dollar of taxpayer spending is valued at a dollar; (3) the only benefit of reorganizing firms when $L>R$ is job creation (yielding, along with (1) and (2), $\alpha=0.25$ ); (4) the number of job-years resulting from a reorganization instead of liquidation is equal to the fifty weeks of unemployment for each worker who would have been employed by the reorganized firm $(l=50 / 52)$; (5) the jobs multiplier $m$ equals two; and (6) the government's "shadow value" of a job during the recession $(G)$ is $\$ 125,000$ per job, then $J=\$ 60,096 .^{58}$ That is, a firm is worth preserving when the cost per direct job to creditors is less than $\$ 60,096 .{ }^{59}$ Of course, one can make different assumptions and better estimates may arise, but the framework remains useful even if the particular numbers are changed.

a. Application to the Chrysler Bankruptcy. - The Chrysler bankruptcy provides an illustrative application of Method One. ${ }^{60}$ Admittedly, the Chrysler case is much more complicated than the binary choice between reorganization and liquidation to preserve jobs, as it involved a government bailout (at least temporarily using taxpayer money) and a questionable distribution to creditors. ${ }^{61}$ Nevertheless, Chrysler's bank-

58. See infra Table 1.

59. This analysis leaves out other potentially relevant factors. For example, the "tax" that creditors face is collected during the recession, which may be more disruptive than taxes collected years after the recession, when taxpayers are likely to pay the bill for stimulus programs.

60. In re Chrysler LLC, 405 B.R. 84 (Bankr. S.D.N.Y. 2009), aff'd, 576 F.3d 108 (2d Cir. 2009), vacated sub nom. Ind. State Police Pension Tr. v. Chrysler LLC, 558 U.S. 1087 (2009), vacated and appeal dismissed sub nom. In re Chrysler LLC, 592 F.3d 370 (2d Cir. 2010) (mem.) (per curiam).

61. In particular, the Chrysler bankruptcy has been criticized for violating the statutory prioritization of creditor repayment. See, e.g., Barry E. Adler, A Reassessment of Bankruptcy Reorganization After Chrysler and General Motors, 18 Am. Bankr. Inst. L. Rev. 305,306 (2010) ("It may seem ... that money otherwise available to repay ... secured creditors was withheld by the purchaser to satisfy unsecured obligations owed the UAW."); 
ruptcy proceedings have been widely viewed as exhibiting a procontinuation bias, and an estimate using this methodology of the value of maintaining its employment during the Great Recession is instructive of the significant stakes involved in counter-cyclical bankruptcy rules. ${ }^{62}$ After its bankruptcy, Chrysler had over 40,000 employees. ${ }^{63}$ Assuming that all of those employees would have been laid off with a liquidation, with an average unemployment spell of fifty weeks and a cost per job of about $\$ 60,000$, the value of this maintained employment is $\$ 2.4$ billion. Under this analysis, if Chrysler had been worth up to $\$ 2.4$ billion more liquidated than reorganized, it still would have been efficient to reorganize.

The estimate for Chrysler could be a substantial under- or overestimate. It may be an underestimate because Chrysler may have an unusually large supply chain, which may have yielded many more layoffs. Indeed, Ford argued in favor of the bailout of Chrysler and GM in part in order to maintain this industrial ecology ${ }^{64}$ In addition, because Chrysler was such a large employer, the glut of workers would have been unusually large and geographically concentrated, ${ }^{65}$ likely leading to especially prolonged unemployment. On the other hand, it may be an overestimate because distinct pieces of Chrysler may have maintained their operations following liquidation. Also, foreign and domestic car producers operating in the United States may have quickly ramped up production-and employment-to make up for the loss of Chrysler. However, unless the job-loss estimate is far too low, the large magnitude of the value of the jobs at stake is clear.

2. Method Two: The Bottom-Up Approach. - An alternative to using the "shadow value" approach is to reconstruct the social benefit of saving a job based on the components of that social benefit. This is the approach of Method Two; however, even if Method One is used, it is instructive to understand what underlies the value of these job-preserving expendi-

Mark J. Roe \& David Skeel, Assessing the Chrysler Bankruptcy, 108 Mich. L. Rev. 727, 733 (2010) ("Unsecured retiree claims were promised well over 50 cents on the dollar, along with control of the New Chrysler, and unsecured trade creditors were promised full payment. The secured creditors, however, were getting 29 cents on the dollar.").

62. See Roe \& Skeel, supra note 61 , at 767 (discussing the issues associated with the Chrysler bankruptcy).

63. Chrysler had 47,326 employees on December 31, 2009, though these were not all in the United States, which is why the 40,000 figure is a more accurate estimate of their overall U.S. employment. Chrysler Grp. LLC, Annual Report (Form 10-K), at 25 (Dec. 31, 2012), http://www.sec.gov/Archives/edgar/data/1513153/000119312514086806/d648678d10k.htm [http://perma.cc/FC93-AKKP].

64. Jon Healey, Ford's CEO Has No Regrets About Call for Bailout, L.A. Times (Apr. 19, 2012), http://articles.latimes.com/2012/apr/19/news/la-ol-ford-ceo-rebuts-mitt-romney-autobankruptcy-view-20120418 [http://perma.cc/5JPV-CGWW].

65. See Our Locations, Fiat Chrysler Autos., http://www.fcagroupcareers.com/ OurBusiness/OurLocation/Pages/home.aspx [http://perma.cc/D8Y2-B7WN] (last visited July 29, 2016) (showing that all U.S. plants are located in Illinois, Ohio, Michigan, and Indiana). 
tures. This value primarily comes from two sources: from avoiding other government expenditures and from Keynesian stimulus. ${ }^{66}$

First, when a worker becomes unemployed, she is served by a wide variety of programs. ${ }^{67}$ She is usually eligible for unemployment insurance, which pays a certain fraction of a laid-off worker's wages ${ }^{68}$ If the individual is poor enough and meets asset tests, she may be eligible for: Supplemental Security Income, which provides income for the very poor; the Supplemental Nutrition Assistance Program, which provides food assistance for the very poor; Medicaid, which provides health insurance for the very poor; and Temporary Assistance for Needy Families, which provides cash assistance for poor families. ${ }^{69}$

Moreover, with regard to lower-income individuals, the government collects less tax revenue, especially as individuals become eligible for the Earned Income Tax Credit. After a waiting period, workers may be eligible for Social Security Disability Insurance (SSDI), which provides payments to individuals who can claim a disability; there is strong evidence that individuals who used to work but who get laid off often sign up for benefits under SSDI. ${ }^{70}$ Adding these various components together for workers who are unemployed for an average of at least fifty weeks likely yields substantial sums for the government. These sums could be estimated using the Survey of Income and Program Participation, which tracks government payments to individuals and even distinguishes be-

66. Note that the "worker's surplus" that is maintained by sustaining employment is implicitly included in the forgone cost of Keynesian stimulus. When jobs are rationed and too "few" people are employed, spending one dollar to preserve a job preserves worker's surplus-that is, the difference between the amount that the worker is paid and the amount she would be willing to be paid to take the job. With workers willing to work at prevailing wages but unable to find jobs, this worker's surplus is left on the table because of the unemployment. Thus, the value of Keynesian stimulus would reflect this benefit of sustaining employment.

67. This section covers only federal programs. State programs would add additional expenditures.

68. Mankiw, Macroeconomics supra note 2, at 160 ("Although the precise terms of the program differ from year to year and state to state, a typical worker covered by unemployment insurance in the United States receives 50 percent of his or her former wages for 26 weeks.").

69. See generally Shelley K. Irving \& Tracy A. Loveless, U.S. Census Bureau, Dynamics of Economic Well-Being: Participation in Government Programs, 2009-2012: Who Gets Assistance? 1-3 (2015), http://www.census.gov/content/dam/Census/library/ publications/2015/demo/p70-141.pdf [http://perma.cc/468T-534C] (Presenting data on the "participation and characteristics of people who received benefits from ... meanstested assistance programs").

70. See generally Dan Black, Kermit Daniel \& Seth Sanders, The Impact of Economic Conditions on Participation in Disability Programs: Evidence from the Coal Boom and Bust, 92 Am. Econ. Rev. 27, 47 (2002) (examining the relationship between labor-force participation and use of SSDI benefits). 
tween those laid off due to bankruptcy and other reasons. ${ }^{71}$ As used below, $S$ represents the total expected social-insurance and safety-net-program costs per worker. ${ }^{72}$

These forgone government expenditures provide only a lower bound on the value of preserving employment because we must also account for Keynesian stimulus effects. During recessions, governments often try to maintain and increase employment for Keynesian reasons. The value of preserving firms teetering on the edge of liquidation is particularly strong when there is a lack of "shovel-ready" projects. Even President Barack Obama acknowledged that it was difficult finding such projects to get money out the door and people employed. ${ }^{73}$ Having the firm already in place makes it a particularly good pressure point for maintaining employment because the firm is able to do so without the lag in spending and employment that often results from government programs. The government is willing to pay a certain amount of Keynesian stimulus-call this number $K$-purely to avoid the harms from low employment levels, including the loss in economic output and harm to those who cannot find jobs.

Under this approach, the government would compare the efficiency costs of not maximizing the value to creditors with the efficiency costs of raising the funds for social-insurance payments $(S)$ and Keynesian stimulus $(K):{ }^{74}$

$$
\text { Efficiency cost }\left(\frac{L-R}{W}\right)<M C P F(S+K)-\operatorname{Value}(S+K)
$$

Or, following the same reasoning as in the previous subsection, a firm should be reorganized when:

71. Survey of Income and Program Participation, U.S. Census Bureau, http:// www.census.gov/programs-surveys/sipp/ [http://perma.cc/PST2-Z6ZR] (last visited July 29, 2016).

72. The partial funding of social-insurance programs by state and local governments raises the question of whether federal expenditures should be treated differently from state expenditures for purposes of calculating the MCPF. This Article takes the view of global efficiency-that is, federal and state expenditures should be treated the same, notwithstanding the fact that state programs may have a different MCPF. An alternative approach might incorporate the generosity of programs like Medicaid and unemployment insurance in the state in which workers live.

73. David Jackson, Obama Jokes About 'Shovel-Ready Projects,' USA Today (June 13, 2011, 6:07 PM), http://content.usatoday.com/communities/theoval/post/2011/06/ obama-jokes-about-shovel-ready-projects/1\#.UxDdc_ldVUU [http://perma.cc/8CQX-XLVE]. The goal of having shovel-ready projects also motivates Martin Shubik's proposal to have experts prepare a list of shovel-ready projects in case a recession should hit. See Martin Shubik, Levy Econ. Inst. of Bard Coll., A Proposal for a Federal Employment Reserve Authority 2 (2009), http://www.levyinstitute.org/pubs/pn_09_05.pdf [http://perma.cc/X562-2Y9P].

74. Keynesian stimulus $K$ only includes spending that is justified by its stimulusgenerating effect, not spending justified on the basis of reducing government expenditures. To count job-creation costs justified on the basis of avoiding government expenditures would be to count those expenditures twice. 


$$
\frac{L-R}{D}<\alpha \operatorname{lm}(S+K)
$$

Though this is a good formula for understanding the components underlying the more comprehensive measure described in Method One, the measurement difficulties for Method Two are substantially greater than for Method One. Thus, while Method Two is useful for decomposing the "shadow value" used in Method One into its two components, the remainder of the Article focuses on Method One.

\section{Accounting for Context Dependence}

This Article argues that bankruptcy law should act to preserve employment when the unemployment rate is high. This section explores the conditions under which employment-preserving bankruptcy rules should come into effect. It describes how a policymaker could measure $J$, the "shadow value" of preserving a job through bankruptcy in Method One. Economic theory suggests that when unemployment is high, sustaining employment and spending has a Keynesian multiplier, which does not exist when unemployment is low. ${ }^{75}$ The positive externality for other workers of keeping workers employed exists when unemployment is high but not when it is low. Thus, to determine times when overall unemployment can be reduced through bankruptcy law, a judge or policymaker should measure the unemployment rate for the labor market relevant for a worker in a particular time, place, and line of work. Fortunately, as this section emphasizes, the information necessary to make such measurements is available to decisionmakers on a timely basis.

The first input into the relevant unemployment rate that a worker faces is the national unemployment rate. ${ }^{76}$ The overall macroeconomy is the primary driver of unemployment and thus an important indicator for how much a job saved in bankruptcy will reduce overall unemployment. Furthermore, workers can change location and professions, so looking beyond the worker's narrow context is important. Fortunately, unemployment data are publicly released and available to bankruptcy judges or other policymakers with little lag, thereby making nearly current infor-

75. See supra note 31 (describing the functioning of supply and demand in neoclassical labor markets).

76. Headline unemployment rates typically do not include among the unemployed the "discouraged" workers who have left the labor market due to the poor state of the economy. See Labor Force Characteristics from the Current Population Survey, Bureau of Labor Statistics, http://www.bls.gov/cps/lfcharacteristics.htm\#discouraged [http://perma.cc/ C7GZ-YKQ4] (last visited July 29, 2016). Some believe that these workers should be included in the unemployment rate. See, e.g., Christopher Matthews, The Unemployment Report Wasn't Rigged, but It's Not Accurate, Either, Time (Oct. 16, 2012), http://business.time.com/2012/10/16/the-unemployment-report-wasnt-rigged-but-its-notaccurate-either/ (on file with the Columbia Law Review) (arguing that the number of discouraged workers is an important macroeconomic employment statistic). However, their absence does not matter for this analysis as long as the percentage of workers who are discouraged at a given measured unemployment rate is the same across different recessions. 
mation available to decisionmakers and improving the quality of decisionmaking. In particular, the Bureau of Labor Statistics releases its estimate of the national unemployment data for the middle of the previous month on the first Friday of each month. ${ }^{77}$

The second input into the unemployment rate that a worker faces is the timing in the business cycle: The level of the unemployment rate alone is not a sufficient piece of information. Focusing on reducing unemployment is more important at the beginning of the recession, when there are more months in the near term with high unemployment. Although neither bankruptcy judges nor anyone else has a crystal ball showing how unemployment will change with time, the Federal Reserve's unemployment forecasts give an indication of future economic conditions. ${ }^{78}$

A third consideration is the appropriate geographic definition of the "macroeconomy." Over time, people move to places of low unemployment from places of high unemployment. ${ }^{79}$ But, especially in the short run, the United States does not have one national labor market but rather many submarkets. So bankruptcy law needs to choose the relevant macroeconomy, which may be as disaggregated as the metropolitan area or as aggregated as the whole country. Which is more appropriate depends on the relevant labor market for the worker, and that in turn depends on how mobile workers are. Precisely determining how to weigh local versus national unemployment rates is beyond the scope of this Article. Both, however, are relevant to this Article given limited mobility. Estimates of local unemployment rates are also available at a high frequency and with little lag. The Bureau of Labor Statistics releases state and metropolitan-area unemployment estimates for the previous month in the middle of the following month. ${ }^{80}$

77. In addition, the unemployment data are not revised subsequently. The unemployment data come from the Current Population Survey of individuals, which is complete by the time the unemployment data are released. Labor Force Statistics from the Current Population Survey, Bureau of Labor Statistics, http://data.bls.gov/timeseries/ LNS14000000 [http://perma.cc/6GAV-BN6D] [hereinafter Bureau of Labor Statistics, Current Labor Force Statistics] (last visited July 29, 2016). At the same time the unemployment data are released, data on employment are released. See Current Employment Statistics, Bureau of Labor Statistics, www.bls.gov/ces/ [http://perma.cc/ RP5Q-LJQX] (last visited July 29, 2016). These data come from a survey of establishments, and these numbers are revised over the coming two months based on a census of establishments. BLS Information, Bureau of Labor Statistics, http://www.bls.gov/ bls/empsitquickguide.htm [http://perma.cc/KQ42-J2MH] (last visited Aug. 19, 2016).

78. A recent projection is available at: Advance Release of Table 1 of the Summary of Economic Projections to Be Released with the FOMC Minutes, Bd. of Governors of the Fed. Reserve Sys., http://www.federalreserve.gov/monetarypolicy/fomcprojtabl20140319.htm [http://perma.cc/A8VZ-UF8T] (last visited July 29, 2016).

79. See, e.g., Christopher A. Pissarides \& Jonathan Wadsworth, Unemployment and the Inter-Regional Mobility of Labour, 99 Econ. J. 739, 753 (1989).

80. Local Area Unemployment Statistics, Bureau of Labor Statistics, http://www.bls. gov/lau/news.htm [http://perma.cc/KP8N-8EPW] (last visited July 29, 2016) (providing local-area unemployment statistics). 
Finally, the type of worker who would be laid off should also play a role in determining the contexts in which employment-preserving bankruptcy law would be most valuable. Just as there is not one national labor market geographically, there are distinct labor markets for different types of workers. For example, in the recent downturn, job prospects for highskilled workers were substantially stronger than those for low-skilled workers. ${ }^{81}$ Thus, in such a downturn, government expenditures on highskilled workers will tend to be lower and the macrostimulus benefits from preserving their jobs will be lower, since they are likely to be employed relatively quickly even without help from bankruptcy law. ${ }^{82}$ Data on unemployment rates by type of worker are available as quickly as the national unemployment rate. In the same first-Friday-of-the-month data release, the Bureau of Labor Statistics also releases unemployment by sector, race, sex, age, educational attainment, and other features that could be taken into account by bankruptcy law. ${ }^{83}$

\section{IMPLEMENTING COUNTER-CYCLICAL BANKRUPTCY LAW}

This Article argues for bankruptcy law's inclusion of a targeted concern for employment preservation, not the general pro-reorganization policy supported by the Supreme Court and some bankruptcy scholars ${ }^{84}$ Thus, ideally pro-reorganization features would not be "baked in" to the system regardless of the state of the economy. This section proposes ways in which the bankruptcy system could incorporate counter-cyclical bankruptcy rules.

81. See, e.g., Anthony P. Carnevale \& Nicole Smith, Georgetown Univ. Ctr. on Educ. \& the Workforce, The Midwest Challenge: Matching Jobs with Education in the PostRecession Economy 4 (2011), http://files.eric.ed.gov/fulltext/ED525299.pdf [http:// perma.cc/62K4SKZR] (highlighting that job prospects coming out of the 2008 recession were more favorable for skilled workers with postsecondary credentials).

82. In addition, poorer workers have a higher marginal propensity to consume, leading to greater macrostimulus benefits. See John Maynard Keynes, The General Theory of Employment, Interest, and Money 126 (1964) (noting that the multiplier is larger in poorer communities).

83. See Press Release, Bureau of Labor Statistics, Employment Status of the Civilian Population 25 Years and Over by Educational Attainment, http://www.bls.gov/ news.release/empsit.t04.htm [http://perma.cc/4463-QEV7] (last visited July 29, 2016) (providing unemployment data by educational attainment); Press Release, Bureau of Labor Statistics, Unemployed Persons by Industry and Class of Worker, Not Seasonally Adjusted, http://www.bls.gov/news.release/empsit.t14.htm [http://perma.cc/9XZR-LTL2] (last visited July 29, 2016) (providing unemployment data by industry); Labor Force Statistics from the Current Population Survey, Household Data Seasonally Adjusted: A-10. Unemployment Rates by Age, Sex, and Marital Status, Seasonally Adjusted, Bureau of Labor Statistics, http://www.bls.gov/web/empsit/cpseea10.htm [http://perma.cc/ 4AS7-9AL9] (last visited July 29, 2016) (providing unemployment data by age, sex, and marital status).

84. See supra notes 11-12 and accompanying text (noting pro-reorganization policy announced by Supreme Court and citing scholars that support such a policy). 


\section{A. Implementation Using $\S 1112(b)$ Under Current Statute}

One important point at which bankruptcy judges choose between liquidating and reorganizing a firm arises when a party in interest files a motion to convert from a reorganization to a liquidation for "cause" under $\S 1112(b) .^{85}$ This section provides that, "on request of a party in interest," a court may convert a Chapter 11 case to a Chapter 7 case for cause, depending on what "is in the best interests of creditors and the estate." "Cause" is then defined in $\S 1112$ (b) (4).${ }^{87}$ One commonly invoked type of "cause" is that there will be "substantial or continuing loss to or diminution of the estate and the absence of a reasonable likelihood of rehabilitation." 88 The judge has substantial discretion over the meaning of "reasonable." 89 Although the statute does not suggest an explicit comparison of the liquidation and reorganization values, the macroeconomic context should enter the calculus for defining when the probability of rehabilitation crosses the threshold of reasonableness; that probability could be lower in times when preserving employment is important. ${ }^{90}$

Structural bias in bankruptcy law leads to firm managers filing "too many" reorganization petitions, effectively giving judges the opportunity to choose which should be liquidations and which reorganizations. Firm managers file the vast majority of bankruptcy filings, and they tend to prefer Chapter 11 reorganizations over Chapter 7 liquidations. ${ }^{91}$ This preference creates an agency problem that drives the structural bias in favor of reorganization petitions. Since firm managers wish to keep their jobs, and managers are more likely to keep their jobs in a reorganization than in a liquidation, it is widely believed that there is a strong bias toward filing using Chapter 11 instead of Chapter 7, even when the

85. 11 U.S.C. $§ 1112$ (b) (2012).

86. Id. § 1112 (b) (1).

87. Id. §1112(b) (4).

88. Id. § 1112 (b) (4) (A).

89. See George P. Fletcher, The Right and the Reasonable, 98 Harv. L. Rev. 949, 981 (1985) (noting that reasonableness invites both consideration of diverse normative criteria and substantial discretion).

90. Macroeconomists argue that it is important that inefficient firms disappear so that more efficient firms take their place. For example, Professors Ricardo J. Caballero, Takeo Hoshi, and Anil K. Kashyap argue that loans from Japanese banks to firms that would have been insolvent absent these loans prolonged the Japanese stagnation that began in the early 1990s. Ricardo J. Caballero, Takeo Hoshi \& Anil K. Kashyap, Zombie Lending and Depressed Restructuring in Japan, 98 Am. Econ. Rev. 1943, 1944 (2008). This option does not include long-term subsidies-or indeed, any subsidies at all. After restructuring, the firm will have to remain solvent to avoid going into bankruptcy again.

91. See infra note 92 and accompanying text (noting that managers are incentivized to file Chapter 11 bankruptcy). 
reorganization value is less than the liquidation value. ${ }^{92}$ Creditors who believe that the firm is worth more liquidated than reorganized then file a $\S 1112$ (b) motion, allowing bankruptcy judges an opportunity to preserve firms and employment. Without this structural bias, bankruptcy judges would have fewer opportunities to preserve firms in which liquidation value is greater than reorganization value.

Section 105 vests judges with additional discretionary authority to implement counter-cyclical bankruptcy rules. ${ }^{93}$ This section, on the "Power of Court," appears to give bankruptcy judges extraordinary power. Section 105 (a) reads, in its entirety:

The court may issue any order, process, or judgment that is necessary or appropriate to carry out the provisions of this title. No provision of this title providing for the raising of an issue by a party in interest shall be construed to preclude the court from, sua sponte, taking any action or making any determination necessary or appropriate to enforce or implement court orders or rules, or to prevent an abuse of process. ${ }^{94}$

On its face, this provision gives judges broad discretion, though the provision is still delimited by the Bankruptcy Code and used sparingly. ${ }^{95}$ Overall, given the text of the statute, its legislative history, and Supreme Court rulings, ${ }^{96}$ it seems likely that judges have discretion to implement counter-cyclical bankruptcy rules.

In light of these provisions, this Article's proposal actually constrains judicial discretion rather than expands it. Bankruptcy judges already consider the effects of employment when deciding petitions under $\S 1112 .{ }^{97}$

92. See, e.g., Jackson \& Skeel, supra note 7, at 25. The conversion of Chapter 7 to Chapter 11 , covered by $\S 706$, is unlikely to be a very important lever, since few potential candidates for counter-cyclical bankruptcy rules are likely to file under Chapter 7 .

93. 11 U.S.C. $§ 105$.

94. Id. §105(a).

95. For example, in In re Kmart Corp., Judge Easterbrook noted that $\S 105$ provides the power to "implement rather than override," so judges' actions must advance provisions of the statute and cannot contradict the code. 359 F.3d 866, 871 (7th Cir. 2004).

96. See Baker Botts v. ASARCO, 135 S. Ct. 2158, 2169-70 (2015) (stating that bankruptcy courts have "broad discretion to decide what constitutes 'reasonable compensation”); Law v. Siegel, 134 S. Ct. 1188, 1194 (2014) ("A bankruptcy court has statutory authority to "issue any order, process, or judgment that is necessary or appropriate to carry out the provisions of' the Bankruptcy Code ... it may also possess 'inherent power ... to sanction "abusive litigation practices."” (quoting 11 U.S.C. $§ 105(a)$; Marrama v. Citizens Bank of Mass., 549 U.S. 365, 375-76 (2007))); United States v. Whiting Pools, Inc., 462 U.S. 198, 204 (1983) (noting the broad scope of the bankruptcy estate).

97. See, e.g., In re 1701 Commerce, LLC, 477 B.R. 652, 659 n.23 (Bankr. N.D. Tex. 2012) (ordering the continuation of a bankruptcy stay to protect the public interest, based in part on judicial notice of the importance of the estate to local economic development); see also In re Surgical Assocs., Inc., No. 13-10081-R, 2013 WL 1176233, at *6 (Bankr. N.D. Okla. Mar. 21, 2013) (denying a $\$ 1112$ motion partly because a potential dissolution of the debtor would "jeopardiz[e] . . . the economic futures of 39 employees" and again not mentioning the state of the economy). 
They invoke the goals of job preservation and value to creditors, which may conflict, but do so in a way that does not rigorously consider the value of a saved job. ${ }^{98}$ This Article offers a systematic way for bankruptcy judges to address this trade-off. It recommends procedures through which judges would consider whether the bankruptcy takes place during a time of high unemployment and suggests a method for measurement. A systematic approach would cabin the discretion bankruptcy judges currently have to consider employment.

Finally, implementing counter-cyclical bankruptcy rules through $\S 1112$ (b) need not dramatically complicate bankruptcy trials. Under $\S 1112$ (b), experts for creditors and management already present information on the valuation of the firm and the likelihood of rehabilitation. ${ }^{99}$ Implementing counter-cyclical bankruptcy rules only calls for a few additional pieces of information that a judge could input into a standard formula: the number of employees working at the firm, the state of the national and local economy, the timing in the business cycle, and the types of workers. ${ }^{100}$ The analysis admittedly involves some parameters that are difficult to measure exactly, but the educated guesswork involved need not greatly complicate the proceedings. Management's experts (who will tend to favor reorganization) and creditors' experts (who will tend to favor liquidation) can add this small amount of information to their existing testimony. ${ }^{101}$

\section{B. Other Means of Implementing Counter-Cyclical Bankruptcy Law Under Current Statute}

Section 1112(b) is just one part of the bankruptcy code that judges can use to implement counter-cyclical bankruptcy rules. In practice, after a bankruptcy survives a $\S 1112$ (b) motion-and even before-there are

98. See, e.g., 1701 Commerce, 477 B.R. at 658-59; see also Surgical Assocs., 2013 WL 1176233 , at $* 6$.

99. Robert F. Reilly, Valuation Analyst Guidelines Related to Bankruptcy Expert Reports and Testimony, 29 Am. Bankr. Inst. J. 60, 60 (2010).

100. See supra section II.C (explaining the factors useful for deciding whether a given firm is worth preserving); infra Table 1 and accompanying text (applying these factors, along with example assumptions, to a particular context).

101. Another point at which a bankruptcy judge could conceivably implement counter-cyclical bankruptcy rules is under $\S 1129$, which determines when a judge shall confirm a bankruptcy reorganization plan. Before confirmation, a judge could demand that a plan involve fewer layoffs, for example. The judge's statutory authority to demand such a change, however, is quite limited. Under $\$ 1129(\mathrm{a})(11)$, a plan must be feasible; the section requires that "[c]onfirmation of the plan is not likely to be followed by liquidation, or the need for further financial reorganization, of the debtor or any successor to the debtor under the plan." 11 U.S.C. $§ 1129$ (a)(11). It seems difficult to argue then that a judge could demand more employment in the name of feasibility when such increases in employment are, if anything, likely to reduce the feasibility of the plan. When choosing between two plans that satisfy the conditions of $\S 1129$, however, the judge could consider employment implications. 
many opportunities in which bankruptcy judges can and do promote reorganization. At virtually each stage of the bankruptcy proceeding, judges exercise discretion in ways that make reorganization more or less likely. These decisions will affect the value of the reorganized firm, at the expense of various other parties whose ex ante incentives are distorted by the knowledge that they may face cancellation of their contractual rights in the bankruptcy proceedings.

Take the recent example of the bankruptcy of Patriot Coal, a mining company operating in a high-unemployment industry (coal mining), in a high-unemployment time (early 2013), in a high-unemployment place (Appalachia). ${ }^{102} \mathrm{~A}$ key issue in the bankruptcy was whether Patriot Coal could cancel the collective bargaining agreement of its unionized employees, roughly a third of its total employees, under sections 1113 and 1114 of the bankruptcy code. In deciding to grant Patriot Coal's motion to reject its collective bargaining agreement, the bankruptcy judge said that among the questions affecting the court's decision was the outcome for "the current employees; the fate of the rank and file ... coal miners." ${ }^{103}$ The court also asked, "What effect will this Court's ruling have on local economies, particularly those in mining communities that thrive on the patronage of those affected by the outcome of the 1113/1114 Motion?" 104 In answering these questions, the judge argued:

If Debtors liquidate, the overwhelming majority of Debtors' current employees ... will be unemployed. There is no question that even today, numerous miners remain unemployed from the liquidation of Debtors' former competitors, and Debtors' employees would add to this joblessness. If ... Debtors liquidate, state and federal governments will likely be left to remedy the carnage .... ${ }^{105}$

In rejecting the union's collective bargaining agreement, the firm's unionized employees and pensioners lost, but the firm's employees overall, government finances, and the local economy won. The rejection transformed the company from one in which the liquidation value was greater than the reorganization value to the reverse, and the company has now successfully emerged from bankruptcy reorganized. ${ }^{106}$ Countercyclical bankruptcy rules justify such actions under the right economic circumstances.

Bankruptcy judges already make many similar decisions. The court can effectively set a higher or lower threshold for marginal cases in decid-

102. In re Patriot Coal Corp., 493 B.R. 65 (Bankr. E.D. Mo. 2013).

103. Id. at 130.

104. Id. at 80 .

105. Id. at 137.

106. Id. at 130 (finding that rejecting the collective bargaining agreement was necessary to avoid liquidation); Jacqueline Palank, Court Approves Patriot Coal's BankruptcyExit Plan, Wall St. J. (Dec. 17, 2013, 12:18 PM), http://www.wsj.com/articles/ SB10001424052702303949504579264270807341770 (on file with the Columbia Law Review). 
ing when to lift the "automatic stay," which prevents other parties from exercising their contractual rights so that the debtor can have time to reorganize. ${ }^{107}$ When staying other parties' repossession of assets requires the availability of the debtor's assets to pay off the other parties and the court therefore prevents other parties from exercising their contractual rights, the court can be more or less stringent in requiring "adequate protection." 108 The court also plays a substantial role in deciding when the debtor can use, sell, or lease property. ${ }^{109}$ The list of similar decisions a bankruptcy judge must make continues throughout much of the bankruptcy process. The key point is that bankruptcy judges can and do make decisions to help firms reorganize at the expense of other parties' contractual rights.

\section{Statutory Changes to Implement Counter-Cyclical Bankruptcy Law}

An alternative to adopting counter-cyclical legal rules within the current bankruptcy code is to change the statute, thereby opening up a broad range of options. Any of the options discussed below would address the weakness of the proposals above that, although there are strong biases in favor of a reorganization plan being proposed, such a plan must in fact be proposed for a bankruptcy judge to have the opportunity to alter her rulings to favor maintaining employment at the appropriate times. Exploring these options fully is beyond the scope of the Article, but a few possibilities are worth mentioning. First, the government could spend money to preserve companies in the name of employment. This would effectively remove the distortion to creditor lending and increase the burden on taxpayers, although by a smaller amount than would result from typical government stimulus programs. ${ }^{110}$ One concern might be that this spending could create a moral hazard for firms or result in windfalls, especially if political considerations matter for decisionmakers. ${ }^{111}$

107. 11 U.S.C. $\S 362$ (2012).

108. Id. $\S \S 361-364$.

109. Id. $\S 363$.

110. This result flows naturally from the analysis in the Article. In the same way that the loss to creditors is less than the amount that the government would have to pay through conventional programs to sustain employment, the government could pay the creditors to preserve the firm for an amount less than it would conventionally spend. These are precisely the cases the analysis above attempted to distinguish from cases in which maintaining employment is not worth it.

111. "Moral hazard" is the name for the response of actors to knowledge that they will be compensated if something bad happens to them. Actors engaging in moral hazard choose to adopt more of a behavior that could lead to the bad outcome-for example, a driver engaging in moral hazard drives more dangerously if she knows that car insurance will pay to fix the car if an accident occurs. See, e.g., Tom Baker, On the Genealogy of Moral Hazard, 75 Tex. L. Rev. 237, 238-39 (1996) (defining the concept of moral hazard and investigating its genealogy). In this Article's case, firms might make more risky bets with the knowledge that they could get government financing if they fail. 
A second possibility is to give the government priority in voting for bankruptcy reorganization plans in order to lend additional support to plans when it would be efficient to preserve jobs but creditors may not opt to do so. ${ }^{112}$ The government could become a pseudo-creditor in bankruptcy proceedings. Or the government's right could be limited to proposing a reorganization plan. However, while giving the government a voice would allow it to encourage the reorganization of the firm, adding another voice could complicate already very litigious proceedings and invite some of the same problems arising from the proposal to use government expenditure to preserve companies. A third possibility is to give the employees themselves the opportunity to propose a reorganization plan or priority in voting for a bankruptcy plan commensurate with the job-preserving benefits. This possibility could follow other proposals for giving employees a vote in order to promote efficient bankruptcy on other grounds. ${ }^{13}$ However, such an approach may create the same issues that would arise if the government were awarded a priority vote in these proceedings. ${ }^{114}$

\section{EXAMPLE APPLICATION}

To illustrate how this methodology of taking into account macroeconomic context in bankruptcy proceedings would work, consider two cases in which judges exhibited an explicit goal of promoting reorganization. Both cases were filed in the first half of 2013, when unemployment was still elevated in the United States but with variations among industries and locations. ${ }^{115}$ In one case, the efficiency considerations that underlie counter-cyclical bankruptcy rules support the outcome; in the other, they do not. First, in the Patriot Coal case described in section III.B above, the

112. Another possible statutory change would be to explicitly introduce public-interest considerations into a judge's decision to approve a plan, as is the case for antitrust settlements under the Tunney Act. 15 U.S.C. § 16(e) (2012).

113. In particular, Professor Anthony J. Casey has suggested that the "option-preserving" priority given junior creditors like employees maximizes efficiency in the face of the incentives that drive senior creditors to maximize their own gain at the expense of junior creditors. See Anthony J. Casey, The Creditors' Bargain and Option-Preservation Priority in Chapter 11, 78 U. Chi. L. Rev. 759, 792-96 (2011) (discussing the option-preservation priority mechanism); see also Donald S. Bernstein \& James E. Millstein, ABI Commission: Redemption Option Value Explained, 34 Am. Bankr. Inst. J. 10, 11, 57 (2015) (discussing the implementation of such a proposal).

114. In addition to playing a role in reorganization, the government or employees could play a role in $\S 363$ asset sales.

115. Press Release, Bureau of Labor Statistics, The Employment Situation-June 2013, at 1, tbl.A-14 (July 5, 2013), http://www.bls.gov/news.release/archives/empsit_ 07052013.pdf [http://perma.cc/URK3-2FZW] (noting "the unemployment rate [for June] was unchanged at 7.6 percent"); Press Release, Bureau of Labor Statistics, Regional and State Employment and Unemployment-June 2013, at 1-2 (2013), http:// www.bls.gov/news.release/archives/laus_07182013.pdf [http://perma.cc/8HCS-V59Z] (reporting regional and state variation in unemployment rates). 
court considered the effects of "highly likely loss of jobs of those who need them most-the rank and file [workers]" 116 and made decisions that promoted reorganization. The judge found that the reorganization saved the "overwhelming majority" of Patriot Coal's 4,200 employees from unemployment and noted the very high unemployment rate for miners in Appalachia, where Patriot Coal mined. ${ }^{117}$ With such a large number of workers facing such a difficult macroeconomic environment, the liquidation value of the firm would have to be substantially higher than the reorganization value for liquidation to be efficient. ${ }^{118}$

Next, consider the bankruptcy of Surgical Associates, Inc., an Oklahoma surgical practice. ${ }^{119}$ In that case, the bankruptcy judge refused to grant a $\$ 1112$ motion to dismiss, partly out of concern for "jeopardizing ... the economic futures of [the company's] 39 employees." 120 However, the unemployment rate in the health care sector was low, ${ }^{121}$ and surgeons faced almost no unemployment. ${ }^{122}$ Additionally, Oklahoma had a low unemployment rate of five percent in February 2013, when the motion to dismiss was filed. ${ }^{123}$ Given that these workers faced very strong job-market prospects, reorganizing the firm in the name of employment was inefficient, harming creditors and benefitting workers little. With these facts, even if the liquidation value was only a small amount greater than the reorganization value, liquidation would still be the appropriate remedy.

Applying this methodology to a specific hypothetical case demonstrates its value in allowing a judge to quantitatively distinguish whether considering employment effects is appropriate, as in the Patriot Coal case,

116. In re Patriot Coal Corp., 493 B.R. 65, 138 (Bankr. E.D. Mo. 2013).

117. Id. at 90, 137 (noting that eleven of Patriot Coal's mining complexes were in the Appalachia region).

118. Although the case materials do not give specific values, it must be that the liquidation and reorganization values were similar, since just the value of the collective bargaining agreement was enough to shift Patriot Coal from a firm with liquidation value greater than reorganization value to the reverse.

119. In re Surgical Assocs., Inc., No. 13-10081-R, 2013 WL 1176233 (Bankr. N.D. Okla. Mar. 21, 2013).

120. Id. at *6.

121. The unemployment rate in the education and health services sector in April 2013 was $4.4 \%$. Unemployment Rate-Education and Health Services, Private Wage and Salary Workers, Bureau of Labor Statistics, http://data.bls.gov/timeseries/LNU04032240? data_tool=XGtable [http://perma.cc/Q6X6-PX7C] (last visited July 29, 2016).

122. The unemployment rate for surgeons and physicians in 2012 was $0.8 \%$. John F. Sargent, Jr., Cong. Research Serv., R43061, The U.S. Science and Engineering Workforce: Recent, Current, and Projected Employment, Wages, and Unemployment 9 (2014), http://www.fas.org/sgp/crs/misc/R43061.pdf [http://perma.cc/C5CN-BL3V].

123. Press Release, Bureau of Labor Statistics, Regional and State Employment and Unemployment (Monthly) News Release (Mar. 29, 2013), http://www.bls.gov/ news.release/archives/laus_03292013.htm [http://perma.cc/6AXS-T4TQ]. 
or inappropriate, as in the Surgical Associates case. ${ }^{124}$ Suppose that a judge sought to adopt the view advocated in this Article and applied it through $\S 1112$ (b). ${ }^{125}$ This section offers a hypothetical analysis of this methodology using an editable program that takes into account various factors, which are listed in Table 1 along with the assumptions, data, and sources used. Definitively developing such a calculation is beyond the scope of the Article, but an example illustrates the implementation of countercyclical bankruptcy rules.

Overall, the goal is to compare the benefits with the costs of preserving a job through bankruptcy. To calculate the benefits, one must take into account the economic conditions that the laid-off workers (and others affected by the liquidation) would face over the period that workers are affected by the decision to liquidate. Recall from section II.C.1 that the value of a preserved direct job during the recession, $J=\alpha \operatorname{lm} G$, was estimated as $\$ 60,096$, which depends upon the ratio of distortion between taxation and reducing payments to creditors $\alpha$, the conversion between direct jobs preserved and job-years created directly $l$, the Keynesian multiplier $m$, and the shadow value of a job during a recession $G .{ }^{126}$ The key in applying this number or one like it to a given situation is to make the value appropriate to the particular state of the economy. Thus, this section demonstrates how to vary this number depending upon $u$, which this Article defines as the unemployment rate for affected workers, and then applies the method to the illustrative situation that begins the Article.

This benefit of a job preserved then needs to be compared to the cost of a job preserved through bankruptcy, $\frac{L-R}{D}$. As described in section II.C.1, the numerator of the formula is the difference between liquidation value $(L)$ and reorganization value $(R)$, and the denominator is the number of jobs directly preserved by reorganizing rather than liquidating the firm $(D)$.

Figure 1 shows this comparison between the benefit and cost of preserving a job. If the reorganization value is greater than the liquidation value (i.e., the cost of a job saved is negative), the firm should definitely be reorganized. At the other extreme, if the cost of a job saved is greater

124. Compare In re Patriot Coal Corp., 493 B.R. 65, 137 (Bankr. E.D. Mo. 2013) (noting that if the debtors liquidate, the majority of their employees will lose their jobs), with In re Surgical Assocs., 2013 WL 1176233 at *6 (denying a motion to dismiss partly because the debtor's dissolution would "jeapordiz[e] the . . . economic futures of 39 employees").

125. See supra section III.A for how $\$ 1112$ (b) could be used. A similar analysis could be done using other provisions of the Bankruptcy Code, as explained in section III.B, or through changing the law, as explained in section III.C.

126. A more complicated model might take into account the value of preserving jobs as the unemployment rate changes over time following a bankruptcy and the full distribution of the duration of averted unemployment, but this analysis does not consider those factors. Also, for simplicity, this Article ignores discounting, which is likely not a significant factor over the time ranges considered here. 
than $J$, the firm should definitely not be reorganized. In the middle, though, when the cost of a job saved is between 0 and $J$, counter-cyclical bankruptcy rules make a difference.

\section{FIGURE 1: OPTIMAL REORGANIZATION AS A FUNCTION OF COST OF PRESERVING A JOB}

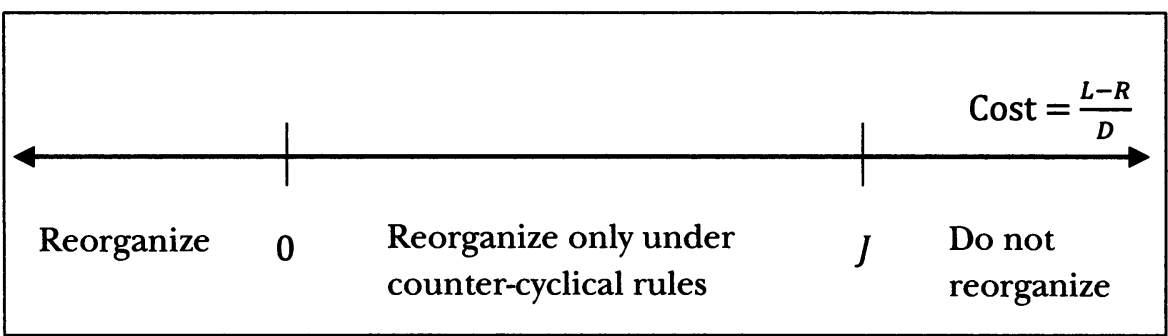

Turning to measuring the benefit of preserving a job $J$, the analysis depends upon measuring the unemployment rate for affected workers. To measure this rate, one must make several choices; other decisions would also be reasonable. In the calculations presented here, four factors affect $u$ : the national average unemployment rate, the unemployment rate of the state in which the firm's workers are employed, the unemployment rate of individuals with characteristics (in this case, educational attainment) typical of the firm's workers, and the expected future unemployment rate.

The unemployment rate must then be translated into the value of a preserved job. To calculate $J$ as a function of $u$ over this time period, the $\$ 60,096$ value per job for the most recent recession is pegged to an unemployment rate of $9.45 \%$, which was the average unemployment rate of 2009-2010. ${ }^{127}$ This value per job is then phased out to zero dollars as the unemployment rate drops to the "natural rate of unemployment."128 For the natural rate of unemployment, the estimate of $6.20 \%$ by Professors Douglas Staiger, James H. Stock, and Mark Watson is used. ${ }^{129}$ At this unemployment rate, the value of a job saved is zero.

127. Labor Force Statistics from the Current Population Survey, Bureau of Labor Statistics, http://data.bls.gov/timeseries/LNS14000000 [http://perma.cc/3469-YKXY] (last visited July 29, 2016).

128. In particular, this value is linearly scaled out as the unemployment rate for affected workers drops from the unemployment rate during the recession of $9.45 \%$ to the natural rate of unemployment.

129. Douglas Staiger, James H. Stock \& Mark W. Watson, How Precise Are Estimates of the Natural Rate of Unemployment, in Reducing Inflation: Motivation and Strategy 195, 199 (Christina D. Romer \& David H. Romer eds., 1997), http://www.nber.org/chapters/ c8885.pdf [http://perma.cc/N8B5-3KRE] (providing a standard citation on the natural rate); see also Thomas B. King \& James Morley, In Search of the Natural Rate of Unemployment, 54 J. Monetary Econ. 550, 556 (2007) (providing a more recent estimate). 
To apply this framework, suppose Acme Corp. is located in Michigan, typically employs high-school graduates with no college education, and went bankrupt in February 2009. In March 2009, a judge is deciding whether to liquidate or reorganize the firm in a $\$ 1112$ (b) motion. First, the judge would need to calculate the value of a job saved $J$, which depends upon the unemployment rate for affected workers $u$. The information with which to calculate $u$ is available from two sources. These data, along with the relevant assumptions and sources, are listed in Table 1. From the Bureau of Labor Statistics, a bankruptcy judge would know that the national unemployment rate in February 2009 was $8.3 \%,{ }^{130}$ the unemployment rate in Michigan was $12.0 \%, 131$ and the unemployment rate of high-school graduates with no college education was $8.5 \% .{ }^{132}$ To estimate the "effective current unemployment rate" ( $E$ in Table 1), these three numbers are averaged to $9.6 \%$. The expected future unemployment rate over the duration was between the $8.65 \%$ expected rate in 2009 and the $8.15 \%$ expected rate the following year in 2010 , according to the Federal Reserve. ${ }^{133}$ For this analysis, the expected future rate of unemployment ( $F$ in Table 1$)$ is the average of these two figures. Averaging the current unemployment rate and the expected future unemployment rate yields an unemployment rate of affected workers $(u)$ of $9.00 \%$.

Note that there is evidence that the natural rate varies with time, which this analysis ignores.

130. Bureau of Labor Statistics, Current Labor Force Statistics, supra note 77. The historical and present national unemployment rates are available at the Bureau of Labor Statistics's website. Id. Note that the Bureau of Labor Statistics only provides estimates to the tenths, not the hundredths, of a percentage point. Id.

131. Press Release, Bureau of Labor Statistics, Regional and State Employment and Unemployment (Monthly) News Releases (Mar. 27, 2009), http://www.bls.gov/ news.release/archives/laus_03272009.htm [http://perma.cc/2BY9-26EE].

132. Data Retrieval: Labor Force Statistics (CPS), Bureau of Labor Statistics, http://www.bls.gov/webapps/legacy/cpsatab4.htm (on file with the Columbia Law Review) (last visited Sept. 26, 2016) (follow "Table A-4. Employment status of the civilian population 25 years and over by educational attainment" hyperlink; then select all under "Not Seasonally Adjusted" and "Seasonally Adjusted"; then select "Retrieve Data").

133. Bd. of Governors of the Fed. Reserve Sys., Minutes of the Federal Open Market Committee on January 27-28, 2009, http://www.federalreserve.gov/monetarypolicy/ fomcminutes20090128ep.htm [http://perma.cc/56FJ-ZRSH]. 
TABLE 1: SAMPLE CALCULATION FOR BANKRUPT FIRM IN FEBRUARY 2009

\begin{tabular}{|c|c|c|}
\hline Variable & Value & Data Source / Derivation \\
\hline \multicolumn{3}{|l|}{ Baseline Value per Job Preserved } \\
\hline $\begin{array}{l}\text { Ratio of distortion from tax on taxpayers } \\
\text { versus creditors }(\alpha)\end{array}$ & 0.25 & $\begin{array}{l}\text { Ballard et al. and } \\
\text { assumptions }\end{array}$ \\
\hline $\begin{array}{l}\text { Average unemployment duration of displaced } \\
\text { worker (in years) }(l)\end{array}$ & 0.96 & Farber \\
\hline Keynesian multiplier $(\mathrm{m})$ & 2 & Chodorow-Reich et al. \\
\hline Value of a job-year $(G)$ & $\$ 125,000$ & $\begin{array}{l}\text { White House Council of } \\
\text { Economic Advisers }\end{array}$ \\
\hline Baseline value per job preserved $(B)$ & $\$ 60,096$ & Multiply the 4 previous values \\
\hline \multicolumn{3}{|l|}{ Effective Current Unemployment Rate } \\
\hline Current national unemployment rate & $8.3 \%$ & Bureau of Labor Statistics \\
\hline Current local (Michigan) unemployment rate & $12.0 \%$ & Bureau of Labor Statistics \\
\hline $\begin{array}{l}\text { Current unemployment rate for typical } \\
\text { worker (high-school graduates with no } \\
\text { college education) }\end{array}$ & $8.5 \%$ & Bureau of Labor Statistics \\
\hline Effective current unemployment rate $(E)$ & $9.6 \%$ & Average the 3 previous values \\
\hline \multicolumn{3}{|l|}{ Forecasted Unemployment Rate } \\
\hline $\begin{array}{l}\text { Forecasted unemployment rate in current } \\
\text { year }\end{array}$ & $8.65 \%$ & Federal Reserve \\
\hline Forecasted unemployment rate in next year & $8.15 \%$ & Federal Reserve \\
\hline Forecasted unemployment rate $(F)$ & $8.40 \%$ & Average the 2 previous values \\
\hline \multicolumn{3}{|l|}{ Scaledown Factor for Value per Job Preserved } \\
\hline $\begin{array}{l}\text { Unemployment rate associated with baseline } \\
\text { value }(T)\end{array}$ & $9.45 \%$ & $\begin{array}{l}\text { Unemployment rate during } \\
\text { Great Recession }\end{array}$ \\
\hline Unemployment rate for affected workers $(u)$ & $9.00 \%$ & $\begin{array}{l}\text { Average current }(E) \text { and } \\
\text { forecasted } \\
(F) \text { unemployment }\end{array}$ \\
\hline Natural rate of unemployment $(N)$ & $6.20 \%$ & Staiger et al. \\
\hline $\begin{array}{l}\text { Scaledown factor for value per job preserved } \\
(H)\end{array}$ & $86.15 \%$ & Formula: $(u-N) /(T-N)$ \\
\hline Value of a job preserved in February $2009(J)$ & $\$ 51,775$ & $\begin{array}{c}\text { Multiply baseline }(B) \text { by } \\
\text { scaledown factor }(H)\end{array}$ \\
\hline
\end{tabular}

The assumptions of section II.C. 1 of a Keynesian multiplier $m$ of 2, a ratio of the distortion from increasing taxes to the distortion from reducing payments to creditors $\alpha$ of $0.25,{ }^{134}$ and a conversion of direct employment into preserved job-years of 0.96 (or 50/52) yield an estimated value per job during the recession of $\$ 60,096$ ( $B$ in Table 1). ${ }^{135}$ An unemployment rate for affected workers of $9.00 \%$ yields a scaledown factor $(H$

134. The calculations assume that the distortion from the government raising the revenue to save a job is equal to the distortion from "taxing" creditors to save a job-that is, the ratio of the distortion from the "creditor tax" to the MCPF is one. The calculations also assume that a dollar of government spending produces something worth a dollar, while the difference between liquidation value and reorganization value is pure waste.

135. See supra note 59 and accompanying text. 
in Table 1) of $86.15 \%$ by which to multiply the baseline value per job preserved ( $B$ in Table 1 ) of $\$ 60,096$, which is associated with a $9.45 \%$ unemployment rate. Multiplying the baseline value per job preserved by the scaledown factor yields a $J$ of $\$ 51,775$. $^{136}$

When considering whether to convert Acme Corp.'s bankruptcy proceedings into a Chapter 7, the judge should then compare this benefit of preserving jobs to the costs of preserving a job, as calculated by estimating the liquidation value $(L)$, reorganization value $(R)$, and the number of workers that Acme Corp. employs. For this calculation, return to the figures in this Article's initial example. Suppose that the liquidation value of Acme Corp. is $\$ 1,500,000$, the reorganization value is $\$ 1,000,000$, and the number of jobs preserved is 1,000 . The cost of a job saved is therefore $\$ 500$, which is far less than the value of a job saved of $\$ 51,775$. This firm should be reorganized, producing $\$ 51,775,000$ of value and avoiding the distortion resulting from $\$ 125,000,000$ in government expenditures at a cost of $\$ 500,000$ to creditors. Different assumptions would yield different numbers, but this example illustrates how the benefits of preserving a firm can greatly exceed the costs of doing so.

\section{RESPONDING TO POTENTIAL CRITIQUES}

\section{A. Institutional Competency of the Bankruptcy System}

Though, as described earlier, counter-cyclical bankruptcy rules need not be implemented through the current bankruptcy system, ${ }^{137}$ a natural critique of implementing them through the current system is that bankruptcy judges lack the necessary competence. For example, Professor Schwartz notes " $[a] s$ an example of bankruptcy's comparative disadvantage, bankruptcy courts do not have access to local labor market information, but state unemployment offices do," thereby making the latter a superior institution for reducing unemployment. ${ }^{138}$ There are several responses to this argument.

First, bankruptcy judges already exercise a tremendous amount of discretion and take employment effects into account. ${ }^{139}$ Bankruptcy

136. Another parameter that could be changed in the calculation is how this number is scaled down. Here, the figure was scaled down linearly, but it could be scaled down more quickly or slowly. Or an entirely different method of calculating it could be used.

137. See supra section III.C.

138. Alan Schwartz, A Contract Theory Approach to Business Bankruptcy, 107 Yale L.J. 1807, 1819 (1998).

139. See Nicola Gennaioli \& Stefano Rossi, Judicial Discretion in Corporate Bankruptcy, 23 Rev. Fin. Stud. 4078, 4078 n.1 (2010) ("For example, U.S. Chapter 11 leaves bankruptcy courts discretion on issues such as first-day orders, refinancing, extensions of exclusivity, appointments of trustees, and the final approval of a reorganization plan.”); Stuart C. Gilson, Managing Default: Some Evidence on How Firms Choose Between Workouts and Chapter 11, 4 J. Applied Corp. Fin. 62, 64-65 (1991) ("[T]he 
judges sit in equity. By $\S 105$, they explicitly have tremendous power to implement the goals of the bankruptcy code, ${ }^{140}$ which-legislative history suggests-includes preserving employment. ${ }^{141}$

More importantly, observers already believe that bankruptcy judges exercise their discretion in a way that favors the continuation of the firm. ${ }^{142}$ Hence, the counter-cyclical bankruptcy rules do not require judges to exercise any discretion that they do not already exercise but instead only to exercise it more effectively; such rules require that judges put a thumb on the scale in favor of reorganization in times of high unemployment and that they refrain from doing so in times of low unemployment. The crucial data on unemployment rates are readily available, ${ }^{143}$ and I suggest a method of applying the data so that the proposal actually constrains judicial discretion.

Finally, even conceding that it might be undesirable for bankruptcy judges to have the additional burden of judging the state of the macroeconomy, the right question is not whether bankruptcy judges are good decisionmakers for this purpose. Rather, the question is whether they are the best available decisionmakers in this arena. It might be better to have an omniscient and benevolent social planner decide which firms must stay in existence via reorganization, but no such institution exists. We are left with the institutions we have-and, therefore, if taxpayers are to save a substantial amount of money at relatively little expense to creditors and no statutory changes are made, then bankruptcy judges ought to be the ones to implement counter-cyclical bankruptcy rules. Indeed, the desire to keep bankruptcy law and job-creating government programs simple is

Bankruptcy Code effectively requires judges to set corporate operating policies ... [meaning] judges have broad powers to influence how the firm's assets are managed."); Harvey R. Miller, The Changing Face of Chapter 11: A Reemergence of the Bankruptcy Judge as Producer, Director, and Sometimes Star of the Reorganization Passion Play, 69 Am. Bankr. L.J. 431, 433 (1995) ("In contrast to the debtor-in-possession, the role of the bankruptcy judge has come almost full circle to be equivalent to the role played by the judge under the Bankruptcy Act, augmented by the power to take numerous actions sua sponte.").

140. 11 U.S.C. $\S 105$ (2012).

141. See supra note 11.

142. See Gennaioli \& Rossi, supra note 139, at 4078-80 (presenting a model that suggests judicial discretion plays a substantial role in creating "systematic pro-debtor bias in the bankruptcy code"); Troy A. McKenzie, Judicial Independence, Autonomy, and the Bankruptcy Courts, 62 Stan. L. Rev. 747, 777-78 ("On bankruptcy-specific questions, bankruptcy judges enjoy significant discretion."); Morrison, supra note 14, at 392-93 ("Traditional accounts of Chapter $11 \ldots$ argue that the bankruptcy process is biased in favor of preserving businesses that are economically distressed and should be liquidated immediately."); see also supra note 97 (providing decisions applying $§ 1112$ (b) that consider employment effects). Finally, for Supreme Court cases suggesting that bankruptcy should favor continuation of the firm, see supra note 11 .

143. See supra notes 76-83 and accompanying text (describing availability and nature of unemployment data). 
appropriate-but it may be worth some sacrifice in simplicity to pursue other worthwhile goals. ${ }^{144}$

\section{B. Asymmetry with Law Outside of Bankruptcy}

Another potential critique of this Article's proposal is that outside of bankruptcy, firms can liquidate as much as they please, regardless of bankruptcy law's attempts to preserve firms intact if they enter bankruptcy. This proposal would then yield an asymmetry between countercyclical rules within bankruptcy and the absence of such rules outside of bankruptcy, causing different treatment for similar firms inside and outside of bankruptcy. Such an asymmetry could deter use of the bankruptcy system, with its associated orderly procedures, and instead encourage settlement of affairs outside of the bankruptcy system. There are two responses to this critique.

First, the scope of the asymmetry may be rather limited, since firms that would ideally be affected by counter-cyclical rules are likely to enter the bankruptcy system; therefore, few firms that would have been realistic candidates for reorganization under counter-cyclical bankruptcy rules will liquidate outside of bankruptcy. The reason for the limited scope of the asymmetry is that counter-cyclical bankruptcy rules are likely to affect a firm with similar reorganization and liquidation values-a firm that, in other words, is a close candidate for being reorganized. This class of firms is likely to enter bankruptcy because those making the decision to enter the system have a preference for reorganization, so that they can keep their jobs ${ }^{145}$ and reorganization is easier within the bankruptcy system. Indeed, the automatic stay and other hallmark features of bankruptcy are designed to solve the collective action problem that arises when creditors pick apart a potentially viable firm. ${ }^{146}$ In other words, the combination of the advantages of bankruptcy for reorganizations and the pro-reorganization bias of management likely means that, in practice, counter-cyclical bankruptcy rules would produce little asymmetry inside and outside of bankruptcy, since few firms outside of bankruptcy would have been reorganized on the basis of such rules had they entered bankruptcy.

144. For additional arguments in the debate over judicial competence in the context of bankruptcy, see Douglas G. Baird, Bankruptcy's Uncontested Axioms, 108 Yale L.J. 573, 585-86 (1998) (describing the "proceduralist" argument in support of a limited role for judges); Ted Janger, Crystals and Mud in Bankruptcy Law: Judicial Competence and Statutory Design, 43 Ariz. L. Rev. 559, 593-96 (2001) (supporting a more expansive role for judges).

145. See Jackson \& Skeel, supra note 7, at 24-25 (noting that firms and their employees have incentives to prefer reorganization over liquidation).

146. See Thomas H. Jackson \& Robert E. Scott, On the Nature of Bankruptcy: An Essay on Bankruptcy Sharing and the Creditors' Bargain, 75 Va. L. Rev. 155, 160 (1989) (noting that resolving such collective action problems is a "principal justification" for bankruptcy law). 
Second, as with the issue of institutional competence, the ideal tool for solving this problem may not exist. All else equal, having similar policies inside and outside of bankruptcy may be ideal. But if that is not an option while having counter-cyclical bankruptcy rules, then it may be best to have different treatments inside and outside of bankruptcy. Some inefficiency could arise from a small number of firms being discouraged from entering bankruptcy due to counter-cyclical bankruptcy rules-and that efficiency should be taken into account in the rules. But the fact that it would be too onerous to implement similar policies outside of bankruptcy because the government lacks tools to do so does not mean that it is undesirable to include such rules within bankruptcy law.

\section{Alternative Policies Would Be Superior}

It may be more efficient for bankruptcy law to preserve employment during recessions than to have laid-off employees rely upon the welfare state and government stimulus programs given their attendant costs to the taxpayer. This is not a sufficient argument for implementing countercyclical bankruptcy rules if there is another option that would be superior to either such bankruptcy rules or existing government programs. For example, some have argued that job-training programs would be more effective in helping those unemployed due to bankruptcies. ${ }^{147}$ However, job training does not help those who cannot find jobs. Indeed, empirical evidence suggests the limited effectiveness of such policies over the time horizon relevant for sustaining employment during a recession. ${ }^{148}$ Others have suggested that unemployment offices can help the unemployed find jobs. However, this assistance appears to be of little help. Interviews with unemployment counselors suggest that, even with a lot of effort, it can be difficult to find a job during a recession; there simply are not enough jobs to go around, and more help on the job market will not change that. ${ }^{149}$

The existence of a policy that would be more efficient than countercyclical bankruptcy rules at reducing costs to the government from unemployment cannot be ruled out. However, it is unclear where the silver bullet would come from. Congress's effort to reduce unemployment during the Great Recession was certainly not perfect, but it represents a good guess of the policies that can be used to reduce unemployment during recessions-and the program was very expen-

147. See Eric A. Posner, The Political Economy of the Bankruptcy Reform Act of 1978, 96 Mich. L. Rev. 47, 53-54 (1997) (suggesting that no scholar has shown that reorganization more effectively mitigates social harm than the welfare state).

148. See David Card, Jochen Kluve \& Andrea Weber, Active Labour Market Policy Evaluations: A Meta-Analysis, 120 Econ. J. F452, F453 (2010) ("Classroom and on-the-job training programmes are not particularly effective in the short run, but have more positive relative impacts after two years.").

149. See Truman F. Bewley, Why Wages Don't Fall During a Recession 341-43 (1999). 
sive. ${ }^{150}$ Congress simply did not find cheap ways of sustaining employment. And this "good guess" is the very set of programs used in this Article as a measure of costs. The key point is that such programs impose a cost on taxpayers, and in some cases, that burden can be reduced substantially through bankruptcy law at relatively little cost to creditors.

\section{Re-Entry into Bankruptcy}

Fourth, one might be concerned that firms with a greater liquidation value than reorganization value are likely to fall back into bankruptcy. Indeed, these so-called "Chapter 22s" (because of the second Chapter 11 filing) are quite common, perhaps partly due to the existing "pro-reorganization" bias in bankruptcy law. ${ }^{151}$ However, from the perspective developed in this Article, re-entry into bankruptcy after reorganization is not necessarily a bad thing. Even if the factory eventually liquidates, delaying the time at which its workers enroll in Medicaid and other government programs is valuable, especially if the original bankruptcy proceedings occurred at the trough of a recession. In addition, some reappearances make sense even in good times. Whether or not a firm will succeed is usually uncertain, so many firms that have a positive expected value will file again. But, during recessions, even more of those firms should stay around-and then refile later, during better economic times, because of their positive employment effects in the short run. ${ }^{152}$

\section{E. Few Bankruptcies Take Place During Times of High Unemployment}

A final potential critique is that few bankruptcies take place during times of high unemployment. It is true that the unemployment rate is often low. However, as Figure 2 shows, bankruptcy filings are strongly counter-cyclical; there are many more when the unemployment rate is high. ${ }^{153}$ As a result, the fraction of bankruptcies that occur when the

150. See Alan S. Blinder \& Mark Zandi, How the Great Recession Was Brought to an End 3 (2010), http://www.economy.com/mark-zandi/documents/End-of-Great-Recession.pdf [http:// perma.cc/8Y7G-SP2U] (tabulating congressional expenditures in response to the Great Recession).

151. See Edward I. Altman, Evaluating the Chapter 11 Bankruptcy-Reorganization Process, 1993 Colum. Bus. L. Rev. 1, 6; Edward I. Altman et al., Post-Chapter 11 Bankruptcy Performance: Avoiding Chapter 22, 21 J. Applied Corp. Fin. 53, 53-54 (2009).

152. A related concern might be the $\S 1129$ requirement that, for a judge to approve a plan of reorganization, the judge must find that "the plan is not likely to be followed by the liquidation, or the need for further financial reorganization." 11 U.S.C. §1129(a)(11) (2012). However, as described in section III.B, after the variety of steps that judges take in the name of promoting reorganization, firms affected by counter-cyclical bankruptcy rules are likely to exit in a relatively strong position and will likely not face liquidation upon exit.

153. Labor Force Statistics from the Current Population Survey, Databases, Tables \& Calculators by Subject, Bureau of Labor Statistics, http://data.bls.gov/timeseries/ LNU04000000 (on file with the Columbia Law Review) (select "1980" in "From" date field; 
economy is in a recession is higher than the fraction of time that the economy is in a recession. Also, even if only a small fraction of bankruptcies are affected, the stakes are large, as the Chrysler example showed. ${ }^{154}$ Preserving jobs through bankruptcy during recessions has the potential to save the government considerable resources and substantially increase efficiency.

\section{FIGURE 2: BUSINESS BANKRUPTCY FILINGS AND UNEMPLOYMENT RATE}

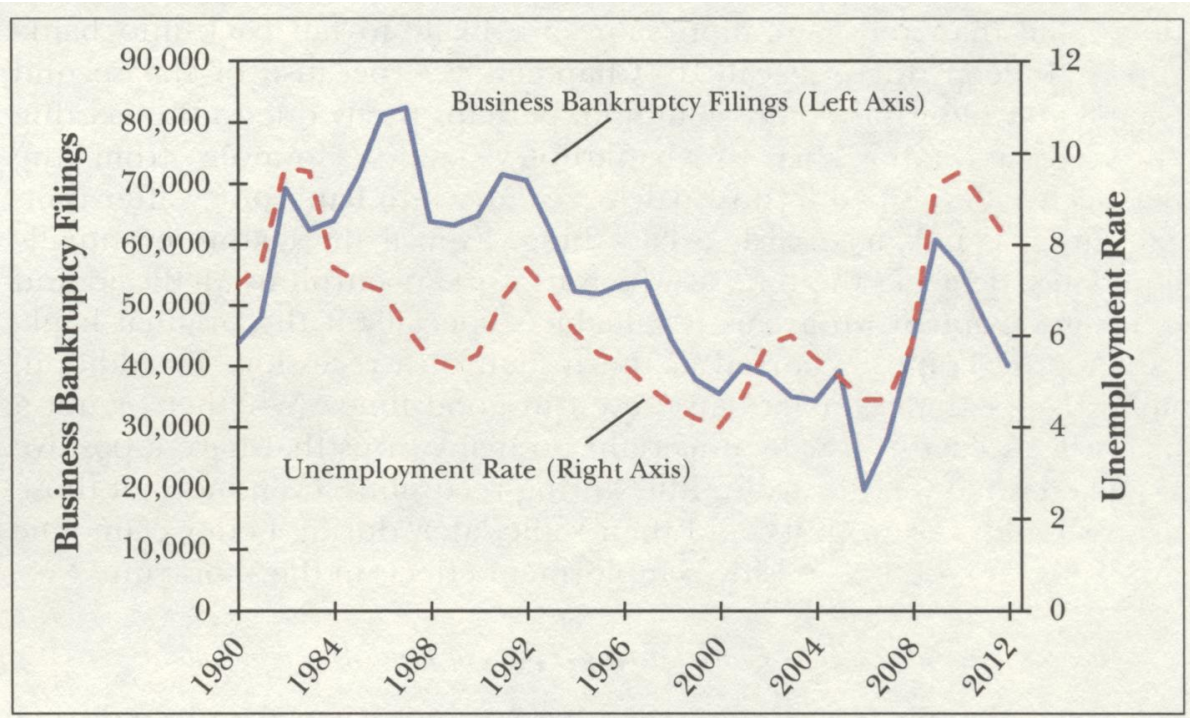

\section{CONCLUSION}

This Article argues that an efficient bankruptcy law should seek to preserve employment during recessions. Preserving jobs when the unemployment rate is high reduces the need for government expenditures on social-insurance payments and leads to Keynesian multipliers, which increase overall employment and efficiency in the economy. Without any change in the law, judges could implement such a counter-cyclical rule using $\S 1112$ (b) and other sections of the Bankruptcy Code. Or Congress could enact statutory changes to permit government expenditures on reorganizations or grant the government quasi-creditor status in bankruptcy proceedings. This Article has also discussed relevant factors like the local and forecasted unemployment rates and shown that data are readily available to help consider these factors. This Article does not argue that, on average, bankruptcy law should be any more employmentpreserving than it is now or that judges should have more discretion. Ra-

then select "2012" in "To" date field; then select "Go" hyperlink) (last visited Sept. 27, 2016).

154. See supra notes $60-65$ and accompanying text. 
ther, this Article argues that, during times of high unemployment, judges or other policymakers should use the method proposed herein to sustain employment in some cases. These counter-cyclical bankruptcy rules constrain judicial discretion in the interest of greater efficiency. Outside of recessions, this Article supports the traditional law and economics argument that bankruptcy law should maximize the return to creditors.

More broadly, the Article suggests a framework for thinking about macroeconomic considerations in the law. The methodology for measuring the shadow value of a job saved could be applied to other areas of the law. For example, the goal of preserving jobs more cost-effectively during times of high unemployment could inform cost-benefit analysis of regulations. Such policies would increase efficiency, help encourage economic recovery, and maintain employment for workers desperately in need of jobs. 